Chemically-oscillating reactions during the diagenetic oxidation of organic matter and in the formation of granules in late Paleoproterozoic chert from

\title{
Lake Superior
}

DOMINIC PAPINEAU ${ }^{1,2,3}$, ZHENBING SHE $^{4}$, MATTHEW S. DODD $^{1,2,3}$

1 London Centre for Nanotechnology, 17-19 Gordon Street, University College London, London, UK.

62 Department of Earth Sciences, University College London, London, UK.

73 Centre for Planetary Sciences, University College London, London, UK.

84 School of Earth Sciences, China University of Geosciences, Wuhan, China.

9

10

11

12

13

14

15

16

17 Revised manuscript submitted for publication in Chemical Geology

18

19

20

21

22

23

24

25

26 
Abstract ( 380 words)

Filamentous and coccoidal microfossils have been reported since the 1950's from a range of granular cherts from the Late Paleoproterozoic southwestern Superior Craton, Canada-United States. However, the chemical and mineral compositions of granules, the presence of microfossils in granules, and the common presence of granules in intercolumnar space of stromatolitic chert are poorly documented and explained. Furthermore, the depositional model for the origin of granules in wave-agitated waters does not entirely explain their mineral diversity nor their characteristic morphologies and patterns. We report on the crystallinity of organic matter, mineral diversity, and compositions of microfossils in granules from three different kinds of late Paleoproterozoic cherts, namely phosphatic, organic, and haematitic. Stromatolitic organic-rich chert from the Gunflint Fm contains granules with euhedral carbonate and equidistant concentric laminations of organic matter, akin to fractal patterns from the Belouzov-Zhabotinsky (B-Z) chemically-oscillating reaction. These granules also contain authigenic anatase, ferric-ferrous silicates, and Fe-oxides. Filamentous and coccoidal microfossils similar to those of the Gunflint occur in chert from the Biwabik Formation and share morphology, and co-occur with Mn-siderite and apatite. Granules in phosphatic chert in the Michigamme Formation often contain filamentous and coccoidal microfossils composed of organic matter, sericite, and apatite. Bulk carbonate associated with these Michigamme granular phosphatic chert beds has systematically negative $\delta^{13} C_{\text {carb }}$ values around $-3.1 \pm 0.9 \%(1 \sigma)$ and $\delta^{18} 0_{\text {carb-smow }}$ between +20.8 and $+30.7 \%$, which suggest some contribution from the diagenetic oxidation of organic matter. Notably, residual carboxylic acid is detectable in C-XANES spectra of organic matter from granular phosphatic chert, which is a residual reactant of B-Z type reactions. Along with previously reported observations of pyritised microfossils from the Gunflint Formation, these distinct mineralogies indicate variable 
modes of preservation for the products of chemically-oscillating reactions that likely relate to the availability of different oxidants in the diagenetic environment. We conclude that the Late Paleoproterozoic shallow-marine environments of the Lake Superior area were populated by morphologically similar micro-organisms, and that the diagenetic oxidation of organic matter through chemically-oscillating reactions contributed to the formation of spheroidal rosettes, granules, and concretions during a late Paleoproterozoic Great Putrefaction Event. Diagenetic spheroids in chert that contain organic matter or microfossils thus provide a reliable petrographic context to search for a record of putrefaction of microbial life on the early Earth and on other ancient planetary surfaces.

Keywords: phosphorite, jasper, apatite, Proterozoic, organic matter, carbon isotopes, concretion, granule, Raman, XANES

Highlights: 3-5 bullet point 125 characters each

1- Microfossils are sometimes preserved in granules from Late Paleoproterozoic chert in Lake Superior area.

2- Diagenetic carbonate in Michigamme chert associated with apatite granules has negative $\delta^{13} \mathrm{C}$ values.

3- Some minerals in granules form from precursor reaction products.

4- Carboxyl in biomass likely plays a role in chemically-oscillating reactions.

5- Chemically-oscillating reactions need to be considered in future interpretations of diagenetic spheroids. 


\section{Introduction}

After the end of the greatest unprecedented perturbation in the carbon cycle (the Lomagundi-Jatuli Event or LJE) and associated Great Oxidation Event (GOE) about two billion years ago (Karhu and Holland, 1996), a number of biological evolutionary changes took place in Earth's biosphere (Papineau, 2010). This is the time when unusual mineralogies associated with stromatolites, granules, and microfossils first became widespread. These biologicallyinfluenced rock types include organic-rich, haematitised, phosphatised, and pyritised stromatolitic and granular cherts in a range of marine environments, including some in proximity to hydrothermal activity. However, there is still no satisfactory comprehensive model for the formation of granular chert that relates their mineralogy, geochemistry, sedimentology, and micropaleontology. For example, rounded granules present in ferruginous cherts have been interpreted as detrital or re-worked structures formed in high-energy environments, with wave action causing the rounded morphology of granules. Many arguments to support this model have been used over the years and include: 1) the similarity of granules with carbonate oolites, which have internal concentric structures and form in shallow-marine wave-agitated water (Lougheed, 1983; Sommers et al., 2000), although oolites in themselves are increasingly regarded as a product of biological activity (Brehm et al., 2003; Pacton et al., 2012), 2) the narrow size range of observed granules, typically from a granules were fully-formed and either plastic or brittle before final deposition (Lougheed, 1983), 4) the occurrence of haematite granules associated with algal fragments and detrital quartz grains suggest a dynamic shallow water environment (Gruner, 1946; French, 1968), 5) and their common association with siliciclastic sedimentary rocks. However, many of these observations could also be explained by concretionary-type growth of granules, for instance 
A chemically-oscillating reaction known since the 1950's, the Belousov-Zhabotinsky

106 (B-Z from hereon) reaction, involves the spontaneous out-of-equilibrium oxidation of the 107 carboxylic acid malonate with bromate-bromine and sulphate. Under standard conditions, 108 this reaction is known to produce characteristic, millimetre to decimetre in size, fractal 109 patterns of concentric circles, rounded or curved equidistant laminations, spirals, individual 110 single spots, and cavity-like structures, variably accompanied by $\mathrm{CO}_{2}$ bubbles (Fig. 1). While 111 some of those patterns are akin to those found in agate geodes, the single-spot patterns in 112 particular (Fig. 1e, 1f) are akin to millimetric to centimetric ooids and peloids. Such 113 spontaneous reactions could occur during sedimentary diagenesis as ferric oxides and other 114 oxidants can contribute to oxidise organic remains. This organic oxidation, or putrefaction, 115 might be facilitated by the presence of extracellular polymeric substances derived from 116 microorganisms. The concentric nature of many granules (e.g. Lougheed et al., 1989; Maliva et 117 al., 2005) combined with common outward-radiating acicular crystal further suggest the 118 possibility of an internal or authigenic process of formation for at least some granules. 119 Chemically-oscillating experiments thus show that fractal patterns occur in millimetre to 120 centimetre sizes and that they share similarities with some features in the rock record. Wave-action is unlikely to produce delicate curved equidistant laminations often seen 122 in granules. Any formational model for granules should also be compatible with the observed 123 carbonate minerals in these structures from chert and associated Banded Iron Formations 124 (BIF) and Iron Formations (IF) that have systematically negative $\delta^{13} C_{\text {carb }}$ values, which is an 125 important clue consistent with the oxidation of OM during diagenesis (e.g. Heimann et al., 126 2010). During the degradation of biomass, chemicals such as $\mathrm{HCO}_{3}{ }^{-}, \mathrm{HS}^{-}, \mathrm{NH}_{4}{ }^{+}$, and $\mathrm{PO}_{4}{ }^{3+}$ are 127 released and hence could become mineralised in carbonates, sulphides, phyllosilicates, and 128 phosphates as concentrically-layered diagenetic spheroids. We thus aim to test a new model 129 for granule formation, which recognises the facts that biomass is rich in carboxylic acids (as 130 they are found in phospholipids, amino acids, and intermediary metabolites) and that various 
131 oxidants can occur in different oxidation states in the environment, thereby setting the stage 132 for out-of-equilibrium conditions such as those illustrated in Fig. 1.

In general, granules are taken here to be millimetre-size sub-spheroidal structures

134 with distinct concentric mineral layers in chert, and often between stromatolite columns or in 135 horizons above stromatolite beds. In haematitic chert (i.e. jasper), laminations are dominated 136 by haematite (Lougheed, 1983), whereas in organic-rich chert, laminations in granules are composed of OM (Lanier, 1989). Granule interiors are often coarse-grained and because of 138 their variable concentricity and mineralogy, they have been alternatively referred to as 139 peloids (e.g. Knoll and Simonson, 1981; Lanier, 1989; Hiatt et al., 2015), pisoids (e.g. 140 Simonson, 1985), and ooids (e.g. Hofmann, 1972; Buick, 1992; Sommers et al., 2000). These 141 reports document diverse types of microscopic rounded structures with interiors 142 characterised by various minerals, grain sizes, and textures, which are collectively grouped 143 here and called 'granules'.

The objective of this study is to provide a comprehensive geochemical and 145 sedimentological documentation of mineralogically different granular cherts in order to 146 better understand both the biological and non-biological processes of putrefaction and the 147 possible role of chemically-oscillating reaction in organic-rich siliceous oozes. The focus of 148 this study is on late Paleoproterozoic granular cherts from the southwestern margin of the 149 Superior Craton, namely from the near-synchronous Michigamme, Biwabik, and Gunflint 150 Formations. Granular cherts of nearly the same age from a unique region hold the potential to 151 preserve evidence for how the oxygenation of surface environments resulted in the 152 preservation of diagenetic structures and the preservation of microfossils.

\section{Geology and samples}

During the accretion of supercontinent Nuna (Laurentia) in the SW Superior Craton, 
157 These events took place between 1.85 and 1.83 Ga (see Shultz and Cannon (2007) and 158 references therein) and resulted in the closing of many coeval basins with hydrothermal 159 activity that delivered vast quantities of Fe on the seafloor, now preserved as Banded Iron 160 Formations (BIFs) of the Cuyuna, Mesabi, Iron River, Marquette, Gogebic, and Gunflint ranges 161 (Fig. 2a). The Penokean Orogen is thought to have ended by 1.84 Ga (Schneider et al., 2002) 162 and to have resulted in the suture of island arcs and the Wisconsin Magmatic Terrain south of 163 the Superior Craton (Van Wyck and Johnson, 1997). Regional volcanism at 1.88 Ga 164 (Rasmussen et al., 2012) was swiftly followed by widespread hydrothermal activity and the 165 deposition of late Paleoproterozoic BIFs. Notably, if the younger rocks of the 1.15 to $1.10 \mathrm{Ga}$ mid-continental rift (Heaman et al., 2007) are removed from the map in Figure 2a and the 167 Superior BIFs are stitched back together, the time-correlative late Paleoproterozoic BIF168 pelite-chert successions of the Cuyuna and Mesabi ranges in Minnesota, the Iron River, 169 Gogebic, and Marquette ranges in Michigan, and the Gunflint range of west Ontario would 170 form a continuous mostly linear belt more than $600 \mathrm{~km}$ long (Schulz and Cannon, 2007). The 171 Animikie Group of Ontario and Minnesota thus has an equivalent in the Baraga Group of 172 Michigan such that the Rove Fm is synchronous to the Michigamme Fm (Nelson et al., 2010). 173 The late Paleoproterozoic basins of Michigan's Upper Peninsula have thus been dissected and 174 extended in an aulacogen toward the southeast during the late Mesoproterozoic mid175 continental rift leaving the Marquette, Gogebic, and Iron River ranges on the south side of 176 Lake Superior (Ojakangas et al., 2001). Metamorphic grades generally increase towards the 177 southwest such that the Gunflint formation is generally considered to be the least affected by 178 metamorphic recrystallization. Metamorphic grades in the Gunflint Fm are below the lower 179 greenschist facies, whereas the Biwabik and Michigamme formations have been 180 metamorphosed at the sub-greenschist to greenschist facies, respectively. Collectively, the 181 BIFs of the Animikie and Baraga Groups include various types of chert-associated mineralogy 182 and sedimentology, including stromatolitic and granular jasper (Lougheed, 1983; Maliva et al., 
183 184 185 186 187 188

2005), cherty stromatolites with grey and red haematite columns (Shapiro and Konhauser, 2015), coarse and fine laminated grey-red Fe-silicate BIFs (i.e. taconite) and grey magnetite cherty BIFs (French, 1968). Age constraints include precise U-Pb ages on zircons, which give an age of 1.878 Ga to 1.836 Ga for tuff beds of the Gunflint Fm and 1.874 Ga for the Hemlock volcanics that intrude the Negaunee Fm below the Michigamme Fm (Fralick et al., 2002; Rasmussen et al., 2012).

Samples in this study come from the Gunflint, Biwabik, and Michigamme formations. Black chert samples from Gunflint Fm (samples GF-1 and GF-7) were collected from the type locality at Schreiber Beach (Fig. 2b; Tyler and Barghoorn, 1954). Black cherts from the Gunflint Fm contain unambiguous and exceptionally well-preserved microfossils (Tyler and Barghoorn, 1954; Schopf et al., 1965; Awramik and Barghoorn, 1977; Lanier, 1989; Wacey et al., 2013; 2012; Brasier et al., 2015). In the correlative Biwabik Fm of the Mesabi range in Minnesota (Fig. 2a), there is stromatolitic jasper with columns that vary between about 1 and $3 \mathrm{~cm}$ in diameter and intercolumns with haematite-magnetite granules (sample $M E$-B1) (Fig. 2c; Gruner, 1946; Lougheed, 1983; Shapiro and Konhauser, 2015). Samples of concretionary jasper (sample AG1108) from Thunderbird mine dumps came from the 'Upper Cherty' member of the Biwabik Fm (Fig. 2d). Lastly, in the Huron River locality at Big Eric's Crossing locality of the Baraga Basin in Michigan's Upper Peninsula, the Michigamme Fm contains silicified argillaceous sedimentary rocks that formed in a shallow-marine environment with decimetre-size stromatolites (Fig. 2e) and centimetre-size apatite concretions (sample MA0708) (Fig. 2f). Samples from the MMTU drill core (Michigan Technological University) came from the Mulligan Creek locality in the Dead River Basin (Fig. 2a).

\section{Analytical methods}

3.1. Optical microscopy and $\mu$ Raman imaging 
Optical microscopy was performed with an Olympus BX51 microscope with 4X, 10X,

$20920 \mathrm{X}, 50 \mathrm{X}$, and $100 \mathrm{X}$ objectives on $30 \mu \mathrm{m}$ thin sections polished with $0.25 \mu \mathrm{m} \mathrm{Al}_{2} \mathrm{O}_{3}$. No oil

210 immersion was used, but Buelher ${ }^{\circledR}$ epoxy was used to make the thin sections. Micro-Raman

211 imaging was performed at the London Centre for Nanotechnology of the University College

212 London with a WITec $\alpha 300$ Confocal Raman Imaging system. A $532 \mathrm{~nm}$ laser was used and

213 focused at 200X magnification for large area scans and at up to 1000X for smaller area scans.

214 An optic fiber 50 microns in diameter was used to collect a Raman spectrum at a confocal

215 depth at least 1 micron below the polished surface of the thin section. Each pixel was

216 recorded with a typical dwell time of 0.4 to 0.6 seconds. All Raman spectra were corrected for

217 cosmic rays using the cosmic ray reduction function in the WITec Project Four Plus software.

218 For all presented average Raman spectra, pixels from Raman images were selected on the

219 basis of their nearly identical point spectra and the resulting average spectra were corrected

220 with a background subtraction using polynomial fits typically of order 4, 5 or 6. Raman

221 spectral parameters such as peak positions, Full Width at Half Maximum (FWHM), and areas

222 under the curve were extracted from well-resolved Raman peaks of interest in background-

223 corrected spectra, normalised to the spectral baseline, and then modelled with a Lorenz-fitted

224 equation. To extract crystallisation temperature estimates from Raman spectra (Beyssac et al., 225 2002) in the Michigamme chert, the following peaks were used: D1 (around $1345 \mathrm{~cm}^{-1}$ ), G +

226 D2 (around 1605 and $1620 \mathrm{~cm}^{-1}$, respectively). The D3 band at around $1510 \mathrm{~cm}^{-1}$ and the D4

227 band around $1245 \mathrm{~cm}^{-1}$ used in the Lahfid et al. (2010) and Kouketsu et al. (2014)

228 geothermometer were expectedly not resolved, but were nevertheless extracted from Lorenz-

229 fitted equations for the Gunflint, Biwabik, and Michigamme formations (Fig. 3; Table 1),

230 where the low crystallization temperatures make this geothermometer more suitable, but still

231 with uncertainties of more than $50^{\circ} \mathrm{C}$. Raman hyperspectral images of mineral associations

232 were generated by mapping the main peak intensities (or unique peaks) for specific minerals

233 using the WITec Project Four Plus data processing software; the peaks include those distinct 
234 for stilpnomelane $\left(\sim 3620 \mathrm{~cm}^{-1}\right)$, OM $\left(\sim 1600 \mathrm{~cm}^{-1}\right)$, haematite $\left(\sim 1320 \mathrm{~cm}^{-1}\right)$, carbonate $235\left(\sim 1090 \mathrm{~cm}^{-1}\right)$, apatite $\left(\sim 965 \mathrm{~cm}^{-1}\right)$, muscovite $\left(\sim 705 \mathrm{~cm}^{-1}\right)$, magnetite $\left(\sim 670 \mathrm{~cm}^{-1}\right)$, rutile $236\left(\sim 612 \mathrm{~cm}^{-1}\right)$, quartz $\left(\sim 465 \mathrm{~cm}^{-1}\right)$, and anatase $\left(\sim 138 \mathrm{~cm}^{-1}\right)$. All Raman peak positions were 237 read directly from measured average spectra calculated from representative regions with low 238 signal-to-noise and after background removal.

\subsection{Isotope Ratio Mass Spectrometry}

Analyses of microdrilled carbonate powders were performed with a Gas Bench heated at $70^{\circ} \mathrm{C}$ and connected to a ConFlo III system and finally injected into a Delta XL mass spectrometer at the Geophysical Laboratory of the Carnegie Institution for Science. The reproducibility (precision and accuracy) on $\delta^{13} \mathrm{C}_{\text {carb }}$ and $\delta^{18} \mathrm{O}_{\text {carb }}$ values ${ }^{1}$ was better than $\pm 0.5 \%$ o $(1 \sigma)$ and usually better than $\pm 0.2 \%$ o $(1 \sigma)$ for $\delta^{13} C_{c a r b}$ values. Accuracy was evaluated on the basis of repeated measurements of internal calcite standard 'Chi' and dolomite 'Tytyri' as well as with a few analyses of NBS 18 and NBS 19. Carbonate carbon isotope data are reported with a $0.1 \%$ correction and oxygen isotope data were corrected with a $9.7 \%$ shift, based on the average difference between the measured $\delta^{18} \mathrm{O}_{\text {carb }}$ of the internal standard standards and their true values, which is due to instrumental/procedural fractionation. residue was then combusted in a CE2500 Elemental Analyser and injected into a Delta V mass spectrometer through a Conflo III system (Papineau et al., 2013). Reproducibility on $\delta^{13} C_{o r g}$ values was better than $\pm 0.2 \%$ o $(1 \sigma)$ on standards of Peru mud, acetanilide, and better than $\pm 5 \%$ for abundance $(1 \sigma)$ based on the long-term reproducibility of standards.

\footnotetext{
${ }^{1}$ Carbon and oxygen isotope data are reported in the conventional form $\delta^{13} \mathrm{C}_{\text {org }}$ or $\delta^{13} \mathrm{C}_{\text {carb }}=$ $\left[\left({ }^{13} \mathrm{C} /{ }^{12} \mathrm{C}\right)_{\text {microdrill }} /\left({ }^{13} \mathrm{C} /{ }^{12} \mathrm{C}\right)_{\mathrm{PDB}}-1\right] \times 1000 \%$ and $\delta^{18} \mathrm{O}_{\text {carb }}=\left[\left({ }^{18} \mathrm{O} /{ }^{16} \mathrm{O}\right)_{\text {microdrill }} /\left({ }^{18} \mathrm{O} /{ }^{16} \mathrm{O}\right)_{\mathrm{SMOW}}-1\right] \times 1000 \%$.
} 


\subsection{Scanning Electron Microscopy (SEM) and Energy Dispersive Spectroscopy (EDS)}

Earth sciences at University College London. Operating conditions for SEM imaging and EDS analysis included a $15 \mathrm{kV}$ accelerating voltage for an electron beam current of $1 \mathrm{nA}$, and a working distance of about $10 \mathrm{~mm}$. Polished thin sections were cleaned with clean wipes and minutes coating under a current of about $1.8 \mathrm{~mA}$ in $\mathrm{Ar}$ ) for analysis in the SEM. Analyses were calculated by the software using ZAF correction and normalized to $100.0 \%$, which yield an error of about $1 \%$.

\subsection{Synchrotron-based Scanning Transmission X-ray microscopy (STXM)}

Sample preparation for X-ray absorption near-edge structure (XANES) spectral

analysis involved dissolution of whole-rock powder (about 5g) from cherts with a density-

calibrated CsF-HF solution $\left(\rho=1.8 \mathrm{~g} / \mathrm{cm}^{3}\right.$ ) and dioxane treatment (Alexander et al., 2007).

Dioxane was used to generate a separate solution of lower density, which visibly floats on top of the $\mathrm{CsF}-\mathrm{HF}$ in a clear teflon tube, and thus isolating the acid insoluble $\mathrm{OM}$ at the interface between the two solutions. After centrifugation, the acid-insoluble OM was pipetted with sterile disposable plastic pipettes in muffled glass vials, washed twice in $2 \mathrm{M} \mathrm{HCl}$, and rinsed three times in DI water, before drying in a laminar air flow hood. Once dried, small clumps of OM were sampled and mixed with a molten bead of $\mathrm{S}\left(\sim 80^{\circ} \mathrm{C}\right)$ on a glass slide. Upon cooling, 278 the sulphur crystallized and trapped the acid-insoluble OM. The S bead was subsequently 279 detached from the glass slide and glued onto an epoxy stub and microtomed with a diamond 280 knife into $100 \mathrm{~nm}$ slices. Microtome sections of OM were transferred to different $200 \mathrm{mesh} \mathrm{Cu}$ 281 TEM grids coated with silicon monoxide. The $\mathrm{S}$ was removed by sublimation at $\sim 70^{\circ} \mathrm{C}$ in air 282 for a few minutes over a hot plate. 
Samples were analyzed with the polymer STXM beamline 5.3.2.2. at the Advanced 284 Light Source (ALS), Lawrence Berkeley National Laboratory (Kilcoyne et al., 2003). During analysis, the electron current in the storage ring was held constant in "topoff mode" at 500 mA at energy of $1.9 \mathrm{GeV}$, providing a nearly constant flux of photons at the STXM end-station. 287 The dispersive and non-dispersive exit slits were set at $25 \mu \mathrm{m}$. Focusing of the photon beam is 288 produced by a Fresnel zone plate with a spot size of around $30 \mathrm{~nm}$. STXM data were acquired as spectral image stacks (i.e. a series of X-ray absorption images at sequential energies), from which XANES spectra of regions of interest were extracted. The highest spectral resolution 291 (0.1 eV step between subsequent images) was in the 282-292 eV range, where the near-edge spectral features for electronic transitions from core shell states to anti-bonding $\sigma^{*}$ and $\pi^{*}$ orbitals are located. XANES spectra are presented as the ratio of transmission spectra from the region of interest, $I$, relative to background transmission spectra, $I_{0}$, calculated as $\mathrm{A}=$ $\ln \left(\mathrm{I} / \mathrm{I}_{\mathrm{o}}\right)$

\section{Results}

\subsection{Crystallinity of organic matter from Gunflint, Biwabik, and Michigamme cherts}

Raman spectra for OM in granules from the black chert of the Gunflint Fm show highly disordered OM with a broad D1-band peaking at $1344 \mathrm{~cm}^{-1}$ (FWHM between 90 and $130 \mathrm{~cm}^{-1}$ ) and a sharp and intense G-band between 1603 and $1609 \mathrm{~cm}^{-1}$ (FWHM between 45 and $57 \mathrm{~cm}^{-}$

1) (Fig. 3a). These features are consistent with the C-XANES spectra for OM in the Gunflint Fm, which include a weak $285 \mathrm{eV}$ absorption for aromatic $\mathrm{C}=\mathrm{C}$ and resolvable absorptions at 286.8 and $288.6 \mathrm{eV}$, respectively for aromatic alcohol and carboxyl (De Gregorio et al., 2009). Together with the presence of greenalite and exceptionally-preserved microfossils and granules (Lanier, 1989), these characteristics are consistent with metamorphism at the prehnite-pumpellyite facies and with a complex residual organic structure (Vandenbroucke and Largeau, 2007). This is further supported by the presence of aliphatic functional groups 
suggested by Raman peaks in the region of $2700-3000 \mathrm{~cm}^{-1}$ (Fig. 4j), and consistent with $\mathrm{CH}_{2}$

310 and $\mathrm{CH}_{3}$ bonds detected by FTIR analyses of OM in Gunflint microfossils (Igisu et al., 2009). It

311 is unclear whether the broad fluorescence peak centred near $1400 \mathrm{~cm}^{-1}$ represents an 312 analytical artefact, but these have unusually strong Raman scattering in the region expected 313 for OM (Fig. 4m). The metamorphic temperature calculated for OM in the Gunflint Fm is 314 between 200 and $350^{\circ} \mathrm{C}$ (average of $262 \pm 77^{\circ} \mathrm{C}$ ) using Lorenz-fitted D- and G-bands and the 315 equations of Lafhid et al. (2010) and Kouketsu et al. (2014) (Fig. 3 and Table 1). In the Biwabik Fm, OM is frequently associated with haematitic microfossil-like structures, but typically has lower signal-to-noise ratios (Fig. 3c, 3d), which due to the micrometre size of the OM particles. Organic matter from Biwabik has resolvable G-bands between 1569 and $1599 \mathrm{~cm}^{-1}$ (with FWHM around $60 \mathrm{~cm}^{-1}$ ) and D1-bands around 1337-1356 $\mathrm{cm}^{-1}$ (with FWHM between 110 and $130 \mathrm{~cm}^{-1}$ ), which can have interference from the haematite peak around $1320 \mathrm{~cm}^{-1}$ (Marshall et al., 2011; 2013). Interference from the haematite peak combined with low signal-to-noise of the spectra prevent reliable determination of crystallization temperatures, here tentatively estimated between 229 and $280^{\circ} \mathrm{C}$. These new observations are consistent with the notion that metamorphism from the prehnite-pumpelleyite facies to the greenschist facies shifts the position of the G-band toward lower wavenumbers and the D-band toward higher wavenumbers (Schopf et al., 2006).

Raman spectra of $\mathrm{OM}$ associated with apatite coccoids and filaments in the Michigamme cherty phosphorite have intense and narrow D1-bands between 1338 and 1353 $\mathrm{cm}^{-1}$ (full width at half maximum (FWHM) between 44 and $65 \mathrm{~cm}^{-1}$ ) and G-bands between 1567 to $1587 \mathrm{~cm}^{-1}$ (FWHM between 41 and $77 \mathrm{~cm}^{-1}$ ) (Fig. 3e, 3f). These characteristics can be used to estimate the crystallisation temperature using the Beyssac et al. (2002) geothermometer between 352 and $398^{\circ} \mathrm{C}$ and indicate a 'poorly crystalline graphite' structure 333 for this OM, which is characterized by similarly-shaped narrow and sharp G- and D1-bands 334 (e.g. Papineau et al., 2011). X-ray Absorption Near-Edge Structure (XANES) spectra of OM 
335 from this sample revealed significant absorption by the aromatic $\mathrm{C}=\mathrm{C}$ and $\mathrm{C}-\mathrm{C}$ bonds, 336 respectively at 285.3 and $291.7 \mathrm{eV}$ (Fig. 4a), consistent with the crystallinity inferred from 337 Raman spectra (Bernard et al., 2009) and with metamorphic grade at the greenschist facies.

\subsection{Petrology of stromatolitic and granular organic chert from the Gunflint Formation}

The organic-rich stromatolitic and granular chert from the Gunflint Fm in Ontario also contain granules in intercolumnar space and finely disseminated OM preserved in stromatolitic laminae. Stromatolites occur as centimetre-size columns branching in multifurcate and anastomosed columnar morphologies (Fig. 5a-5b), whereas intercolumnar

344 granules are often concentrically-laminated and typically around $500 \mu \mathrm{m}$ in diameter (Fig. 5c; 345 5f). Here, the chert is essentially cryptocrystalline throughout and inter-granular outsized carbonate rhombs are up to $400 \mu \mathrm{m}$ in size. The concentrically-laminated granules contain fine layers of $\mathrm{OM}$ about $10 \mu \mathrm{m}$ in thickness and frequent authigenic-diagenetic euhedral carbonate minerals occur in external layers (Fig. 5g-5j). Some granules contain concentric layers of pyrite (Fig. 5e). Diagenetic euhedral carbonate rhombs also occur in the intergranular spaces between stromatolite columns (Fig. 5k), and these are occasionally replaced by pyrite remobilised from later diagenetic veins (Fig. 5d). Similar euhedral crystals in the Biwabik Fm are composed of gypsum partly replaced by magnetite (Lougheed, 1983). Other large euhedral carbonate crystals several hundred microns in size contain highly fluorescent OM (Fig. 5k-m), analogous to other occurrences from the Gunflint chert where carbonate has been replaced by Fe-oxides (Sommers et al., 2000).

Microscopic filamentous structures and the commonly co-occurring spheroidal structures are relatively common in fine stromatolitic laminations and less common in nonconcentrically laminated Gunflint granules (Fig. 6 and 7). Filaments are 2 to $4 \mu \mathrm{m}$ in diameter with lengths of up to $400 \mu \mathrm{m}$ and they also occur embedded in the laminae of the stromatolite columns (Fig. 6a-g), all consistent with previous observations (Tyler and Barghoorn, 1954). 
361 They are composed of finely disseminated OM (Fig. 6g) that has the usual spectral 362 characteristic of amorphous OM, but sometimes has highly fluorescent domains (Fig. 6h).

363 Spheroidal organic structures range in size between about 6 and $50 \mu \mathrm{m}$ and tend to occur in 364 granules where they can be accompanied by filaments (Fig. 7a-d) and more complex 365 reticulated spheroidal structures (Fig. 7e). In one of the studied granules, spheroidal 366 structures between about 10 and $25 \mu \mathrm{m}$ (Fig. 7f-h) co-occur with diagenetic brown dolomite, 367 which contains OM (Fig. 7i-j).

\subsection{Petrology of stromatolitic and granular jasper from the Biwabik Formation}

Stromatolitic and granular haematitic chert from the Biwabik Fm is characterized by a similar but chemically distinct diagenetic history to the Gunflint and Michgamme cherts. Jasper from the Mary Ellen mine in the Biwabik Fm contains grey magnetite and red haematite granules ( $>200 \mu \mathrm{m}$ in diameter), which occur between millimetre-size multifurcate and anastomosed stromatolite columns made of finely laminated chert and haematite-rich layers (Fig. 8a-8b). Jasper occurrences in the Thunderbird mine include centimetre-sized concretions that are typically flattened and no greater than about $5 \mathrm{~cm}$ in

377 size (Fig. 8c). Granules and concretions are variably composed of finely disseminated, microscopic to nanoscopic red haematite (Fig. 8d-7f). Some granules contain regular patterns of spheroidal haematite structures associated with monazite (Fig. 8e) or central patches of stilpnomelane surrounded by Mn-siderite (Fig. 8f). Fe-oxide minerals that form concentric layers in granules are generally concentrated in layers of similar thickness (Fig. 8g). Some granules are mostly formed of such mixtures of magnetite or haematite with apatite and carbonate both commonly have poikilitic-type textures (Fig. 8h-8k). These authigenic apatite crystals occur as brown subhedral blades more than $100 \mu \mathrm{m}$ in size and are associated with 
equidistant laminations of nanoscopic carbonate and interiors of coarse magnetite, fine 387 hematite, and micron-size particles of OM and carbonate (Fig. 9d-9i).

In the chert-hematite matrix of stromatolite columns, there are micron-size apatite grains that occur as isolated euhedral crystals with nanoscopic inclusions of chert and 390 haematite (Fig. 8k). Filamentous and spheroidal microscopic structures occur in some 391 haematite-magnetite granules and concretions (e.g. Fig. 8c) in association with haematite (Fig. 10, 11). Some granules contain patches of filaments with diameters between 0.5 and $4 \mu \mathrm{m}$ and lengths of hundreds of microns (Fig. 10a-10c). In some other granules, spheroids have sizes typically around $10 \mu \mathrm{m}$ (Fig. 11a, 11b, 11e), although some spheroids have sizes more than $100 \mu \mathrm{m}$ (Fig. 11d). Some spheroids also contain microscopic carbonate (Fig. 10d and inset) and/or micron-size particles of OM (Fig. 11i-l). While some peaks of Biwabik OM are mixed with epoxy (Fig. 10f, 11l), as inferred from the presence of peaks at 2854, 2904, and $2952 \mathrm{~cm}^{-1}$ -attributable to $\mathrm{CH}_{2}$ and $\mathrm{CH}_{3}$ bonds in epoxy, their G-band positions are between 1569 and $1599 \mathrm{~cm}^{-1}$, which indicates an indigenous origin overprinted by sub-greenschist facies metamorphism. Both filamentous and spheroidal structures are composed of finely disseminated red haematite associated with micron-size particles of $\mathrm{OM}$ and cross-cutting stilpnomelane (Fig. 11j), which demonstrates their pre-metamorphic origin.

\subsection{Petrology of granular phosphatic chert in the Michigamme Formation}

Grey chert interlayered with green argillite and carbonate constitutes the main 406 lithologies associated with the Michigamme phosphatic chert at the Mulligan Creek locality. 407 Pyrite and haematite replacing pyrite occur as authigenic disseminations, rosettes, cubes, and 408 occasional massive bands. The dominantly grey chert is banded and often stromatolitic. Chert 409 sometimes occurs as black and white bands and interlayered with argillite rich in OM. Higher 410 in the stratigraphy of the $M M T U$ drill core, the chert contains dark grey granules and wrinkly 411 and finely laminated microbial mats of apatite. In the MMTU drill core, dolomite occurs as 
412

413

414

granules, rhombs, cement, matrix micrite, and microcrystalline dolomite beds and veins. Field exposures in Huron River locality reveal the occurrence of coarsely laminated decimetre-scale domal stromatolitic chert (Fig. 2e). Concretions of apatite form pinching and swelling millimetre-long structures and/or centimetre-size sub-ellipsoidal concretionary masses mixed with the matrix of chert (Fig. 2f, 12a-b).

The studied phosphatic chert samples are dominated by microcrystalline quartz $(<4 \mu \mathrm{m})$, carbonate, apatite, disseminations and structures of $\mathrm{OM}$, haematite, and euhedral to anhedral pyrite. Authigenic apatite is systematically associated with OM and appears diffuse with high-relief brown to dark grey patches in transmitted light (e.g. Fig. 12a). Apatite occurs as millimetre- to centimetre-size apatite-sericite concretions (Fig. 12a-12b) and as granules that are typically more than $200 \mu \mathrm{m}$ in size (Fig. 12d-12i). Granules are usually sub-ellipsoidal and contain disseminated OM that often form a network with a regular pattern (Fig. 12d-12i). There are compartmentalised spheroidal structures around $100 \mu \mathrm{m}$ in size composed of apatite and $\mathrm{OM}$ in the intergranular matrix (Fig. 12j, 12k). Some granules have angular edges that form a sub-hexagonal habit (Fig. 12l-12m) sometimes accompanied by curved equidistant laminations of nanoscopic anatase (Fig. 12n-12o). In some apatite beds (Fig. 12c), there are spheroidal granules of carbonate with fine spheroidally concentric equidistant laminations (Fig. 12p-s) that also contain filaments of OM in their geometric centres (Fig. 12rs).

Apatite in granules and concretions from these rocks is often associated with OM and muscovite-sericite and often occurs as microscopic filamentous and spheroidal structures (Fig. 13, 14). A millimetre- to centimetre-size concretion of apatite contains distinct filamentous structures more than $200 \mu \mathrm{m}$ in length and 2 to $6 \mu \mathrm{m}$ in diameter (Fig. 13a-g). The filaments are composed of $\mathrm{OM}$ and apatite and are intermixed with chert, sericite, haematite, and rutile at the micron scale (Fig. 13f, 13g). Micro-Raman imaging shows that OM systematically occurs in the apatite (Fig. 13g-13h), but it also occurs in association with 
carbonate and chert. Other apatite granules contain a ring of microscopic apatite spheroids each between 10 and $50 \mu \mathrm{m}$ in size with rims enriched in OM (Fig. 14a-14c). These structures are filled with apatite-sericite, which usually contains $\mathrm{OM}$ but sometimes devoid of it, as in the case of euhedral apatite filling some interior (Fig. 14c). A rosette about $60 \mu \mathrm{m}$ in diameter occurs inside the latter granule and is composed of sub-micron-sized radiating acicular muscovite (sericite). Muscovite was identified from its acicular habit, transparent colour (Fig. 14d), low second order birefringence colours (Fig. 14e), Raman peaks at 198, 266, 705, and at 3629 (for hydroxyl) $\mathrm{cm}^{-1}$ (Fig. 14h), and the fact that it contains $\mathrm{K}, \mathrm{Mg}$, and $\mathrm{Al}$ as detected by EDS. The radiating acicular nature of this rosette, best seen in cross polars (Fig. 14e), and its rim of apatite, best seen in BSE images (Fig. 14f), suggests outward or centrifugal growth. The core of muscovite in this granule is surrounded by an outer layer of quartz (about 80-100 $\mu \mathrm{m}$ thick) with various minerals: spheroidal grains of apatite coated with $0 M$, euhedral anatase crystals 4 to 10 microns in size, and diffuse haematite possibly from weathering (Fig. 14g). The composition of apatite in the Michigamme Fm is fluorapatite with minor levels of rare Earth elements (Table 2). Raman images show the occasional contamination of the thin section by diamonds and epoxy (Fig. 13g-h), but the graphitic OM is indigenous and systematically associated with apatite.

\subsection{Isotope and molecular compositions of carbon in the Michigamme Formation}

In chert and argillite from the Michigamme Fm at the Mulligan Creek locality (MMTU samples), there is typically less than $1.5 \mathrm{wt} \%$ of total organic carbon (TOC), and levels average at $0.4 \pm 0.4$ wt $\%(1 \sigma)$ (Fig. 15 , Table 3 ). The $\delta^{13} C_{\text {org }}$ values vary between -20.8 and $-46.7 \%$ o with an average of $-26.2 \pm 4.8 \%(1 \sigma)$. There are only two chert samples that have a $\delta^{13} C_{o r g}$ value below $-35 \%$ (Fig. 15; Table 3). The pyrite-bearing chert sample at $27.1 \mathrm{~m}$ has a $\delta^{13} \mathrm{C}_{\text {org }}$ value of $-44.5 \%$ and occurs just before about 10 metres of stromatolitic chert beds. The chert sample at $3.5 \mathrm{~m}$ has a $\delta^{13} \mathrm{C}_{\text {org }}$ value of $-46.7 \%$ and is directly overlain by the first two metres of 
464 drill core, which consists of chert-bearing dark grey clumps of apatite seen in all samples 465 above $3.3 \mathrm{~m}$. These observations show that highly ${ }^{13} \mathrm{C}$-depleted $\mathrm{OM}$ can occur before the 466 stratigraphically overlying stromatolites followed by phosphate-rich concretionary-granular 467 chert beds. In comparison, the phosphatic chert from the Huron River locality (MA0708) has 468 variable $\delta^{13} C_{\text {org }}$ values on millimetre scale between -26.7 and $-35.3 \%$ (Fig. 12b). The carbon 469 isotope composition of carbonate minerals in Michigamme chert is systematically negative 470 and with $\delta^{13} \mathrm{C}_{\text {carb }}$ values between -1.4 and $-5.2 \%$ with an average of $-3.1 \%$ and $1 \sigma$ standard 471 deviation of $0.9 \%$ (Fig. 15; Table 3). These compositions are also characterized by highly ${ }^{18} 0$ 472 enriched values between +20.7 and $+10.8 \%$, that yield an average $\delta^{18} \mathrm{O}_{\text {carb }}$ value of $+14.8 \pm$ $473 \quad 2.3 \%$ o $(1 \sigma)$.

Acid-insoluble OM from MA0708 has major C-XANES peaks at $285.3 \mathrm{eV}$ and $291.7 \mathrm{eV}$ 475 (Fig. 4a), typical of $\mathrm{OM}$ in Late Paleoproterozoic stromatolitic phosphorites also 476 metamorphosed around the greenschist facies (Papineau et al, 2016). Weak peaks are 477 resolvable at 287.6 and $288.5 \mathrm{eV}$ (Fig. 4a), which independently confirms the presence of 478 residual aliphatic C and carboxyl respectively (Cody et al., 1996; De Gregorio et al., 2011; 479 Bernard et al., 2012). Such pair of peaks has been reported in OM from unmetamorphosed 480 Cretaceous concretionary and organic-rich shales from Germany (Bernard et al., 2012) and 481 from Late Paleoproterozoic stromatolitic phosphorites from the Jhamarkotra Fm (Papineau et 482 al., 2016). The C-XANES spectra for the Michigamme OM are similar to those of OM from the 483 Gunflint Fm (De Gregorio et al., 2009; Alléon et al., 2016) and in fact to OM in general 484 preserved in metamorphosed sedimentary rocks (Bernard et al., 2007; 2009; 2011). The OM 485 analysed also contains $\mathrm{N}$ as shown with a peak at $404.0 \mathrm{eV}$ that points to N-bearing functional 486 groups (Cody et al., 2011; Fig. 4b), and 0 with peaks at 531.7 and 538.9 eV that point to 487 ketone groups (Fig. 4c - Hitchcock and Biron, 1980).

\section{Discussion}




\subsection{Carbon cycling in chert from the Michigamme, Gunflint, and Biwabik formations}

Evidence for the diagenetic oxidation of OM in the Michigamme Fm is seen in the systematically negative $\delta^{13} \mathrm{C}_{\text {carb }}$ values down to $-5.2 \%$, hence a ${ }^{13} \mathrm{C}$-depleted oxidised source of $\mathrm{OM}$ was assimilated by Michigamme carbonate. Most $\delta^{13} \mathrm{C}_{\text {org }}$ values measured for sedimentary rocks from the Michigamme Fm are within the average composition in the late Paleoproterozoic and, considering the near-zero $\delta^{13} \mathrm{C}$ of seawater at that time, these values are therefore consistent with fractionation by the pentose phosphate pathway for $\mathrm{CO}_{2}$-fixation (Desmarais, 2001; Schidlowski, 2001). For comparison, the Gunflint Fm has similar average $\delta^{13} C_{\text {org }}$ value around $-27 \%$ and down to $-34 \%$ (Strauss and Moore, 1992). Two samples of chert from the Michigamme Fm have $\delta^{13} C_{\text {org }}$ values of -44.5 and $-46.7 \%$ (Fig. 15), which is similar to a small number of analyses from the Gunflint Fm with $\delta^{13} C_{\text {org }}$ values down to 45.8\% that characterise some Huroniospora-like microfossils (House et al., 2000). Such highly ${ }^{13} \mathrm{C}$-depleted values are generally attributed to methane cycling (e.g. Hayes, 1994), and thus observations for the Michigamme Fm possibly point to methanotrophy before a transient episode of stromatolite formation followed by phosphatisation. Similar large ranges of $\delta^{13} C_{o r g}$ values have been reported from sedimentary rocks from the early Paleoproterozoic Hamersley Group in Western Australia and indicate the co-existence of aerobic shallow waters and anaerobic deep waters (Eigenbrode and Freeman, 2006). Michigamme cherts are thus interpreted to have originated in aerobic shallow-marine sedimentary environments where diagenetic processes associated with OM oxidation included a combination of aerobic heterotrophy, methanotrophy, and possibly other metabolic pathways.

In the black chert from the Gunflint Fm, late diagenetic dolomite rhombs occur as outsized crystals between granules (Fig. 5d) as well as smaller crystals within concentric equidistant laminations of $\mathrm{OM}$ (Fig. 5i). Systematically negative bulk $\delta^{13} \mathrm{C}_{\text {carb }}$ compositions in the Michigamme Fm are similar to siderite-bearing rocks from the Gunflint Fm, down to 5.5\% (Winter and Knauth, 1992), and to the Biwabik iron formation between -3.7 and - 
18.6\%o (Perry et al., 1973) (Table 4). These compositions point to carbonate formation from

517 the product of diagenetically-oxidised $\mathrm{OM}$. The $\delta^{18} \mathrm{O}_{\text {SMOW }}$ values from the carbonate in

518 Michigamme Fm average at $+14.8 \%$, which is similarly affected by diagenesis as carbonate in

519 the Biwabik Fm with $\delta^{18} \mathrm{O}_{\text {SMow }}$ values between +10 and $+18 \%$ o (Perry et al., 1973 ) and the

520 Gunflint Fm with $\delta^{18} \mathrm{O}_{\text {Smow }}$ values between +14 and $+23 \%$ (Winter and Knauth, 1992) (Table

521 4). Euhedral pyrite can replace dolomite during later diagenesis (Fig. 5d) and in concentrically-layered granules of haematite in the Gunflint chert, pyrite has $\delta^{34} S$ value of 1\%o (Fig. 13a in Papineau et al., 2005), which does not unambiguously suggest fractionation

524 by microbial sulphate reduction because mantle sulphur also has this isotopic signature. In 525 brief, diagenetic carbonate produced from the oxidation of biomass is interpreted here to be 526 indicated by the presence of 1) direct association with microfossils (Fig. 7b, 7i, 11d), 2) 527 disseminations inside granules (Fig. 5i, 8f, 8i, 8j, 9b, 9g), 3) rounded equidistant laminations 528 in rims of nanoscopic crystals (Fig. 9g, 10d), 4) spheroidal carbonate granules with rounded 529 equidistant laminations (Fig. 12p-12s), and 5) outsized and zoned intergranular 530 rhombohedral crystals (Fig. 5d, 5k).

The graphitization of $\mathrm{OM}$ into graphite is a unidirectional process, and as such the crystallinity of graphitic carbon can be used to estimate crystallization temperatures from 533 Raman D- and G-bands (Beyssac et al., 2002; Lafhid et al., 2010). Metamorphic temperatures 534 derived from Raman spectra of OM in Michigamme cherty phosphorite are between 352 and $535398^{\circ} \mathrm{C}$, which are consistent with metamorphism at the greenschist facies. The diffuse apatite 536 and OM segregated from chert in filamentous microfossils and spheroids probably acquired 537 this glassy high-relief texture (e.g. Fig. 13d) during such thermal metamorphism. Lower 538 metamorphic temperatures between 209 and $333^{\circ} \mathrm{C}$ were calculated for the $\mathrm{OM}$ in the 539 Gunflint Fm, consistent with other estimates (Alléon et al., 2016) and with prehnite540 pumpellyite facies metamorphism. The OM in the Gunflint Fm has three broad peaks at 2649 
$541 \mathrm{~cm}^{-1}, 2934 \mathrm{~cm}^{-1}$, and $3196 \mathrm{~cm}^{-1}$ that indicate a better degree of preservation than in the

542 Biwabik and Michigamme formations.

5.2. The variable preservation of spheroidal and filamentous microfossils

The petrography of microfossils in granules and stromatolite laminae from the Gunflint black chert was first described in detail by Tyler and Barghoorn (1954) whose later systematic description became the taxonomic foundation of Precambrian micropaleontology (Barghoorn and Tyler, 1965). It was then recognized that these microfossils could be preserved as primary $\mathrm{OM}$, or be replaced by pyrite, carbonate, or haematite. Both the Biwabik and Michigamme formations contain spheres and filaments that have identical sizes and morphologies to the well-described microfossils from the Gunflint Fm (Awramik and Barghoorn, 1977; Barghoorn and Tyler, 1965; Cloud and Licari, 1968; Knoll and Barghoorn, 1975; Lanier, 1989; Shapiro and Konhauser, 2015; Wacey et al., 2013). The filaments and spheroidal microscopic structures we report from our samples are morphologically similar to the above as well as to haematitic microfossils from late Paleoproterozoic phosphorite (Crosby et al., 2014) and BIF (Karkhanis, 1976; Shapiro and Konhauser, 2015). They are also compositionally distinct from biomimicking structures grown in so-called 'chemical gardens' (Garcia-Ruiz et al., 2017; Barge et al., 2016). The mineralogical preservation of microfossils in chert is thus likely dependent on the abundance of oxidants such as sulphate, oxygen, and/or haematite during diagenesis.

In granules and intergranular matrix of our samples of the Gunflint black chert, typical Gunflintia minuta comprises straight to slightly sinuous organic filaments, between 1 and 3 $563 \mu \mathrm{m}$ in diameter, and up to several hundred microns in length (Fig. 6). Spheroidal microfossils 564 composed of OM range from 3 to $25 \mu \mathrm{m}$ in diameter (Fig. 7) and they have the typical 565 morphology of Huroniospora. Other well-preserved specimens of Gunflintia and Huroniospora have been analysed in situ by SIMS, which reveals similar ranges of $\delta^{13} \mathrm{C}$ values between -30 
and -38\%o for Gunflintia and Huroniospora (House et al., 2000; Williford et al., 2013). Such

568 compositions are consistent with the pentose phosphate or acetyl CoA metabolic pathways of $569 \mathrm{CO}_{2}$-fixation (House et al., 2003). Morphologically similar microfossils are found in the 570 Michigamme and Biwabik formations, although they have been preserved in different 571 minerals.

In the Michigamme phosphatic chert, spheroidal microfossils composed of OM with apatite occur within granules composed of apatite, chert, muscovite, haematite, and anatase. They occur as spheroidal apatite grains with rims composed of OM and they have diameters between 10 and $50 \mu \mathrm{m}$, similar to the multicellular modern cyanobacteria Chroococcidiopsis sp. (e.g. Knoll and Barghoorn, 1975). These spheroidal microfossils are generally larger than typical Huroniospora or Myxococcoides, but they are also similar to coccoidal microfossils such as Eosphaera tyleri in the Gunflint Fm (Barghoorn and Tyler, 1965), which have a cell wall thickness of about $100 \mathrm{~nm}$ (Brasier et al., 2015). A few discreet occurrences of compartmentalised microfossils composed of apatite and OM occur in the matrix (Fig. 12j, $12 \mathrm{k}$ ) and are similar to some compartmentalised organic microfossils from the Gunflint Fm, also interpreted to share affinity with Chroococcus (e.g. Fig. 8 in Lanier, 1989). Fm and occur inside millimeter-size granules of $\mathrm{OM}$ and apatite mixed with chert (Fig. 13). Their morphologies, sizes, compositions, and mode of occurrence collectively point to an assignment as filamentous microfossils, possibly as Gunflintia minuta. Phosphatic chert from the Michigamme Fm is known to contain pyrite framboids, abundant OM within apatite 588 granules, fossil microbial mat structures, and filamentous apatite structures on the outer 589 coating of some apatite granules, which have been interpreted as microfossils of Fe-oxidising 590 bacteria (Hiatt et al., 2015). In the Paleoproterozoic Zanoega Fm, phosphatic mudstones have 591 layers of apatite concretions that likewise contain tubular filamentous microfossils composed 592 of OM with apatite (Joosu et al., 2015) and some have been interpreted to have formed from 
593

594

sulphur-oxidising bacteria (Lepland et al., 2013). Finally, while a microfossil origin is suspected for the variably patterned networks of $\mathrm{OM}$ and apatite in some granules from Michigamme Fm (Fig. 12d-12i), these are more highly degraded and not unambiguously recognizable as microfossils.

In the Biwabik Fm, another taphonomic variety of Gunflintia and Huroniospora is preserved as dense disseminations of nanoscopic haematite (Barghoorn and Tyler, 1965; Shapiro and Konhauser, 2015). Putative filamentous haematite microfossils can be found inside rare granules from the Biwabik Fm and they have diameters between 0.5 and $4 \mu \mathrm{m}$ along with lengths of tens to hundreds of microns. Similar filaments previously reported in samples from the Corsica mine of the Biwabik Fm have Gunflintia-like filaments with diameters between 1 and $5 \mu \mathrm{m}$ and composed of fine haematite disseminations in chert (Cloud and Licari, 1968; Shapiro and Konhauser, 2015). Some of the filamentous haematite microfossils in the Biwabik Fm share similarities in size and morphology with modern filamentous Fe-oxidising bacteria in the Franklin seamount of Papua New Guinea (Boyd and Scott, 2001). Such filamentous haematite microfossils are similar to others in the Lake Superior area interpreted to have a biological origin (Leith, 1903; Gruner, 1946; LaBerge, 1967; 1973; Lougheed, 1983, Shapiro and Konhauser, 2015).

Other haematite granules contain spheroids typically around $10 \mu \mathrm{m}$ composed of disseminated haematite and accessory carbonate and morphologically resemble Huroniospora (Fig. 11a, 11b, 11e, 11j). In coarse chert laminations inside stromatolite columns, there are micron-size haematitic coccoidal microfossils that are similar to Myxococcoides, smaller but morphologically similar to others preserved in granules. In some haematite granules, there are spheroidal structures with sizes more than $100 \mu \mathrm{m}$ in diameter (Fig. 11c, 11d), which are composed of haematite and carbonate in chert. These large spheroids are not necessarily microfossils; if they are, many specimens would be larger than the large extant cyanobacterium Chroococcidiopsis sp, which are generally smaller than $50 \mu \mathrm{m}$. Alternatively, 
they could be sulphur-oxidising bacteria, akin to Thiomargarita sp., which are known to grow

620 large sizes, sometimes in excess of hundreds of microns, in phosphorites (Schulz and Schulz, 621 2005; Bailey et al., 2007). Cases have also been made for sulphur-metabolising filamentous 622 microfossils preserved in pyrite in late Paleoproterozoic chert from the Duck Creek Fm 623 (Schopf et al., 2015) and for large-size microfossils in the Neoarchean Gamohaan Fm (Czaja et 624 al., 2016). Lastly, similar to regular network patterns in Michigamme organo-apatite granule, some regular patterns of haematite structures in Biwabik granules might represent highly degraded microfossils (Fig. 8d, 8e), but they might not even be microfossils at all. In brief, the 627 filaments and spheroids in Lake Superior chert are preserved either as degraded OM, an admixture of apatite with finely disseminated $\mathrm{OM}$, and associated detrital-diagenetic sericitemuscovite and anatase-rutile, or as partial replacements with pyrite or haematite. Therefore, there are morphological similarities between bona fide filamentous and coccoidal microfossils in granules from late Paleoproterozoic cherts from Lake Superior area and microfossils previously reported, and while these occur in a range of mineral assemblages, some associated specimens are highly degraded.

\subsection{Wave action and the diagenetic oxidation of biomass in the formation of granules}

in individual granules from the Biwabik Fm and specifically proposed that they might be microfossils. Later papers (LaBerge, 1973; Lougheed, 1983) summarized and expanded this earlier work on granules and discussed further the biogenicity of BIFs. Millimetric and submillimetric granules of concentric, equidistant, and laminated OM in black chert from the 641 Gunflint Fm (Fig. 5e, 5g) have the simplest mineralogy of all granules studied and thus are likely an end-member in terms of preservation. Evidence that some granules formed as 643 primary features in a wave-agitated environment includes 1) their occurrence in a unit just 644 above the Pokegama sandstone, a well-sorted orthoquartzite interpreted as a beach or 
645

646

647

648

649

650

651

652

653

654

655

656

657

658

659

660

661

662

663

664

665

666

667

668

669

670

nearshore deposit, 2) association with broken fragments of algal columns, which suggests significant wave and current action, as well as 3) various sedimentological textures and shapes that can be variably interpreted by wave-action or possible Liesegang effects. The presence of hematite in Biwabik granules can be explained by the dehydration of primary ferrihydrite, while the adsorption of these such nanoscopic phases by microbial mats could have contributed to form granules by wave-action during sedimentation. In addition, the cooccurrence of anatase, rutile, and sericite-muscovite in the Michigamme chert suggest that these are detrital particles and that wave action could also have contributed to the rounding of these granules prior to organic degradation. However, the Biwabik and Michigamme granules also preserve mineralogical and textural evidence for oxidised biomass.

The presence of diagenetic carbonate, apatite, magnetite, and stilpnomelane inside granules, such as those from the Biwabik Fm, requires a corollary to the wave-action model; one that takes into account their overall geochemical-mineralogical compositions. Also, some morphological features of the granules remain unexplained by this model, such as granules with concentric equidistant laminations composed of OM (Fig. 5g), pyrite (Fig. 5e), anatase (Fig. 12o), haematite (Fig. 8g) and magnetite (Fig. 10d). A comprehensive model of granule formation should thus take into account all these independent observations, which we suggest involves in situ diagenetic oxidation reactions of $\mathrm{OM}$ during putrefaction of microbial biomass and the resulting formation of granules that form fractal patterns akin to those seen in the $\mathrm{B}-\mathrm{Z}$ reaction (Fig. 1e, 1f).

Organic matter can be oxidised by $\mathrm{Fe}^{3+}$ in the absence of biologically-mediated reactions (Amstaetter et al., 2012; Kohler et al., 2013). The non-biological oxidation of OM during diagenesis can occur according to Equations 1 to 4, depending on the availability of electron acceptor compounds:

$$
\begin{gathered}
\mathrm{CH}_{3} \mathrm{COOH}+3 \mathrm{Fe}(\mathrm{OH})_{3}->2 \mathrm{HCO}_{3}^{-}+\mathrm{Fe}_{3} \mathrm{O}_{4} \bullet x \mathrm{H}_{2} \mathrm{O}+2 \mathrm{H}^{+} \\
\mathrm{CH}_{3} \mathrm{COOH}+\mathrm{SO}_{4}^{2-}->2 \mathrm{HCO}_{3}{ }^{-}+\mathrm{HS}^{-}+\mathrm{H}^{+}
\end{gathered}
$$




$$
\mathrm{CH}_{3} \mathrm{COOH}+4 \mathrm{PO}_{4}^{3-}->2 \mathrm{HCO}_{3}^{-}+4 \mathrm{PO}_{3}^{3-}+2 \mathrm{H}^{+}
$$

$$
\mathrm{CH}_{3} \mathrm{COOH}+\mathrm{BrO}_{4}^{-}->2 \mathrm{HCO}_{3}^{-}+\mathrm{Br}^{-}+2 \mathrm{H}^{+}
$$

673 In these equations, $\mathrm{CH}_{3} \mathrm{COOH}$ is acetic acid taken as a simplification for carboxyl groups in 674 humic acids. Humic acids are essentially alkylated and polyaromatic hydrocarbons with 675 carboxyl, ketone, and alcohol functional groups, and is thus similar to biological OM 676 (Vandenbroucke and Largeau, 2007). This is important because OM with such molecular 677 functional groups can be preserved during the metamorphic maturation of biomass (e.g. 678 Boyce et al., 2002; Bernard et al., 2007; 2009). This background can be used to explore the 679 hypothesis that the concentric equidistant laminated mineral patterns that characterize many 680 cherty, haematitic, phosphatic, clay-rich, and OM-rich granules can be attributed to the 681 preservation of oxidative reaction fronts in chemically-oscillating reactions during diagenesis 682 (Fig. 16).

Organic matter in the Michigamme phosphatic chert has C-XANES spectra that show 684 the residual presence of aliphatic and carboxyl groups (Fig. 4), which have been reported 685 from various other sources of natural carbons (Bernard et al., 2012; Boyce et al., 2002; Cody 686 et al., 1996; De Gregorio et al., 2011; Hitchcock and Ishii, 1987). These functional groups are 687 similar to those from $\mathrm{OM}$ in Triassic fossil spores in limestones, which include ketones, 688 phenols, and carboxylic acids (Bernard et al., 2007), and to OM in the Gunflint Fm, which 689 contains phenols and carboxylic acid as well as strong $1 \mathrm{~s}-\pi^{*}$ and $1 \mathrm{~s}-\sigma^{*}$ transitions of 690 polyaromatic carbon (De Gregorio et al., 2009; Moreau and Sharp, 2004). Together with single 691 broad peaks for OM in the centres of diagenetic dolomite rhombs and broad Raman D-bands 692 that encompass several of these functional groups, these characteristics are further consistent 693 with the presence of heteroatoms of $0, \mathrm{~N}, \mathrm{~S}$, and P in acid-insoluble residues from the Gunflint 694 Fm, and thus a biological origin for this OM (De Gregorio et al., 2009). The heteroatom695 bearing degraded OM, from the Gunflint and Michigamme formations thus originated from 696 biomass that was degraded and oxidized by both biological and non-biological processes. 
In our samples from the Gunflint Fm, we only found evidence for chemicallyprecipitated minerals such as quartz, carbonate, and pyrite, and hence, this is consistent with the compositions of reactants and products of known chemically-oscillating reactions of oxidising microbial biomass, which can be invoked as a major process for these granules. In comparison, the co-occurrence of anatase, rutile, sericite-muscovite, and disseminations of hematite in both the Michigamme and Biwabik chert suggest that these are detrital particles. Wave action may thus also have contributed to the rounding of the granules prior to organic degradation, but the Biwabik and Michigamme granules also preserve mineralogical evidence for oxidised biomass in the form of rosettes, granules, and concretions, which can be considered fractal patterns as they present similar patterns at various scale dimensions. The mineralogical mode of preservation of granule is thus related to the presence of detrital particles, carboxylic acids, and the availability of oxidants in the diagenetic environment, as suggested in equations 1 to 4 .

\subsection{Chemically-oscillating reactions in mineralogy, sedimentology, and micropaleontology}

In the classical B-Z reaction, carboxylic acids are oxidised with bromate-bromide and

713 sulphate while the reaction products include sulphide, brominated organic molecules, and

714 bicarbonate. In natural environments, other oxidants such as phosphoric acid, ferrihydrite, 715 sulphate, and oxidised halogens must contribute to the oxidation of biomass. The products can then include ${ }^{13} \mathrm{C}$-depleted bicarbonate that precipitates as various diagenetic carbonate

717 minerals, phosphate with variable oxidation states (e.g. White and Metcalf, 2007) that 718 precipitates as apatite, hydrogen sulphide that readily forms greigite and pyrite, and ferric719 ferrous hydrated oxides and silicates that can become diagenetic (and metamorphicallycrystallized) magnetite and phyllosilicates. These reaction products then co-exist with the

721 unreactive residue of oxidised biomass, which are polycyclic aromatic hydrocarbons and 722 kerogen that can thermally convert to graphitic carbons. Oxidized wavefronts of OM are 
723

724

proposed here to start from randomly located centres within masses of degrading microbial colonies in silica-saturated waters, expanding centrifugally outward within the chemical sedimentary gel precursor to chert (Fig. 16a). Such non-equilibrium reactions under standard conditions ( $\mathrm{P}=1 \mathrm{~atm}, \mathrm{~T}=298 \mathrm{~K}$; Fig. 1$)$ must be favoured in diagenetic settings in which the limited availability of free water leads to higher (molar) concentrations of oxidants in pore spaces and the production of acid (Eq. 1-4). In the classical B-Z reaction, malonic acid $\left(\mathrm{C}_{3} \mathrm{H}_{4} \mathrm{O}_{4}\right)$ is oxidised with strong oxidants such as $\mathrm{KBrO}_{4}$, which creates out-of-equilibrium concentric redox fronts that propagate away from oxidising sites over minutes time scales (Fig. 1; Zaikin and Zhabotinsky, 1970; Epstein et al., 1983; Vanag and Epstein 2003). The presence of carboxyl groups in OM from the Gunflint and Michigamme formations shows that key residual reactants from the reactions in equations 1 to 4 are preserved in minerals associated with OM and inside granules.

The mineralised products of the proposed chemically-oscillating reactions include carbonate, pyrite, and ferric-ferrous silicates (e.g. stilpnomelane) and oxides (e.g. magnetite), which are variably found within granules (Fig. 16). Notably, some of these minerals in granule rims can precipitate from reaction products in equations 1 to 4 . Characteristic B-Z fractal patterns can thus be recognised as mineralised rims or concentric layers of 1) magnetite, hematite, apatite, and carbonate in the Biwabik chert (Fig. 8h, 9b, 9g), 2) 1) carbonate and pyrite in the Gunflint chert (Fig. 5e, 5i), and 3) apatite, carbonate, graphitic carbon, and anatase in the Michigamme chert (Fig. 12o, 12p-12s, 14g). The systematic occurrence of ${ }^{13} \mathrm{C}-$ depleted carbonate in chert from the Gunflint (Winter and Knauth, 1992), Biwabik (Perry et al., 1973), and Michigamme formations (Tables 3 and 4) points to the oxidation of OM as an important reaction during diagenesis. In brief, the proposed chemically-oscillating reactions during the oxidation of biomass could be mineralised as fractal patterns preserved as laminated concentric and non-intersecting mineral patterns, including granules, rosettes, concretions, and botryoid-type laminations. Botryoids share similarity with B-Z type patterns 
and, while this observation has never been adopted, botryoids have been previously reported in ferruginous-silicified microbial mats and directly associated with microfossils (e.g. Preston et al., 2011). Hence, key diagenetic minerals occurring as mineralised, rounded, concentric, and/or equidistant layers in granules can be interpreted to represent fractal patterns that repeat at multiple dimension scales, and forming from putrefying microbial biomass.

In phosphatic chert from the shallow-marine Michigamme Fm, apatite granules have millimetre sizes and often contain microfossils composed of OM with apatite or degraded microfossil-like patterns. The precursor phosphate to these mineral assemblages was likely concentrated by micro-organisms that would have included cyanobacteria (Benzerara et al., 2014) or by large sulphur-oxidising bacteria (Schulz and Schulz, 2005). The oxidation of putrefying microbial biomass would have generated $\mathrm{HCO}_{3}-$ and $\mathrm{H}^{+}$, lowering alkalinity, and would have triggered diagenetic apatite precipitation. Authigenic apatite forms in pore water solutions under oxic or sub-oxic conditions when fluorapatite supersaturation is achieved (van Cappellen and Berner, 1991; Ruttenberg, 2005). Oxidants such as $\mathrm{O}_{2}$, ferrihydrite, sulphate, and phosphate can contribute to the non-biological oxidation of microbial OM and to the propagation of redox fronts. Anatase and rutile in Michigamme granules is interpreted to be diagenetic minerals that grew from Ti ions in pore water, most likely from a detrital source (Force, 1991). Submicron-size anatase crystals can form concentric layers that envelope some apatite granules (Fig. 12o) and are interpreted to form patterns from chemically-oscillating reactions. Their size is comparable to anatase crystals a few tens of nanometres in diameter, which are thermodynamically more stable than similarly-sized rutile crystals (Gribb and Banfield, 1997). Besides, $\mathrm{TiO}_{2}$ crystals are also known to be excellent photocatalysts that help degrade OM (Fujishima and Zhang, 2006), and thus could have contributed to oxidise biomass during the earliest stages of diagenesis. These reactions are thus proposed to produce spheroidally-concentric B-Z type patterns akin to those in Fig. 1e and 1f around microbial colonies during the diagenetic oxidation of their biomass (Fig. 16). Another useful comparison 
775 is with apatite granules from the Neoproterozoic Doushantuo phosphorite that contain

776

777

778

779

780

781

782

783

784

785

786

787

788

789

790

791

792

793

794

795

796

797

798

799

800

ubiquitous microfossils and rims with rounded equidistant laminations of apatite and pyrite (She et al., 2014), which could have formed from similar processes. Therefore, the origin of granules involves diagenetic chemically-oscillating reactions as seen from the mineral compositions of rounded, equidistant, and laminated patterns.

Microscopic rosettes are proposed to represent fractals one dimension scale smaller than granules, some of which can be also located between stromatolite columns - for instance in the Jhamarkotra phosphorite (Papineau et al., 2016). Siderite rosettes are known to form during diagenetic to low grade metamorphic conditions (at $\mathrm{T}=170^{\circ} \mathrm{C}$ and $\mathrm{P}=1.2 \mathrm{kbar}$ ) in experiments where glucose is oxidised by ferrihydrite to produce siderite (Kohler et al., 2013). Other long-term experiments at room temperature with phosphate and bacteria have further shown that rosettes can develop as individual radially fibrous apatite spheroids, which sometimes forms pairs as dumbbell-shaped structures (Blake et al., 1998). Rosettes with apatite have been reported to occur in a number of rocks, including: 1) in Lower Cambrian and Neoproterozoic phosphorites from China associated with chert and framboidal pyrite (Sun et al., 2014), 2) in the intercolumnar space of stromatolitic phosphorite in late Paleoproterozoic Aravalli Supergroup in India where they also contain carbonate inclusions in apatite and cores of chert (Papineau et al., 2016), 3) in organic-rich chert of the late Paleoproterozoic FB Fm in the Francevillian Supergroup in Gabon where they occur as apatite cores surrounded by quartz and embedded in a matrix of siderite and stilpnomelane (Mossman et al., 2005), and 4) in the Gunflint iron formation where they are composed of siderite, apatite, and haematite or only of siderite or haematite with chert (LaBerge, 1973; Lougheed et al., 1983; Heaney and Veblen, 1991; Carrigan and Cameron, 1991). Many hypotheses have been proposed for the origin of rosettes including fossil cyanobacteria (LaBerge, 1973; Awramik and Barghoorn, 1977; Chauhan, 1979), fossil eukaryotic organisms (Kazmierczak, 1979), structures that crystallize from viscous and impure silica gels (Oehler, 
1976), and as early diagenetic structures (Carrigan and Cameron, 1991; Papineau et al.,

802 2016). In light of our new data, the mineral compositions, and the concentric nature of 803 rosettes shows consistency with a similar mechanism to that invoked for granules: 804 chemically-oscillating reactions during the early diagenetic oxidation of microbial biomass 805 (Fig. 16; Papineau et al., 2016).

\section{Conclusions}

While some granules have a detrital-accretionary origin, for instance when they are composed of detrital phase like clays, titanium dioxide, or hematite, but our new observations suggest that both biological and diagenetic processes were also involved in their formation.

811 The occurrence of ${ }^{13} \mathrm{C}$-depleted carbonate in the Michigamme, Gunflint, and Biwabik

812 formations suggests the oxidation of OM into carbonate. The common co-occurrence of pyrite 813 in these cherts suggest the oxidation of OM during diagenesis in the presence of sulphate.

814 Some highly depleted $\delta^{13} \mathrm{C}_{\text {org }}$ values down to $-46 \%$ in the Michigamme Fm, suggest transient 815 episodes of methane cycling, possibly associated with anaerobic and aerobic microenvironments.

We report new observations of mineral patterns akin to the characteristic fractal patterns from the classical B-Z reaction (Fig. 1) and suggest that these are fractal patterns that 819 form micrometre-size rosettes, millimetre-size granules, to centimetre-plus size of concretions (Table 4). While the morphologies of life forms are often characterised by fractal

821 patterns (e.g. dendrite, stripes, veins) powered in part by the metabolism of carboxylic acids 822 (e.g. the tri-carboxylic acid cycle), other fractal patterns continue to be produced during the 823 putrefaction of biomass and the oxidation of carboxylic acids. Detailed petrographic, 824 mineralogical, and sedimentological documentation of granules in Lake Superior cherts 825 reveals the occasional occurrence of putative microfossils, diagenetic minerals, as well as 826 repeating patterns made of precipitated minerals (quartz, apatite, carbonate, magnetite, 
827 ferric-ferrous phylosilicates). In particular, the presence of carboxyl groups in OM from the

828 Gunflint and Michigamme cherts shows the preservation of residual reactants. Products of B-Z 829 type reactions include precursor molecules to ${ }^{13} \mathrm{C}$-depleted carbonate, as well as pyrite, 830 apatite, and ferric-ferrous silicates (e.g. stilpnomelane, greenalite, vermiculite) and oxides 831 (e.g. magnetite), all of which are considered diagenetic minerals when they occur in granules, 832 most clearly when they have rounded, equidistant, and finely laminated concentric layers. 833 Chemically-oscillating reactions are proposed to significantly contribute to the formation of 834 diagenetic spheroids such as rosettes, granules, and concretions, all of which share 835 similarities with B-Z type fractal patterns, in particular regarding the fact that they preserve 836 similar mineral patterns of concentric equidistant laminations at several dimension scales. 837 We further suggest that the origin of rosettes of muscovite, haematite, apatite, and pyrite are 838 due to such processes during early diagenesis. Under standard conditions, concentric patterns 839 made of reaction products would expand outward through an EPS-silica gel, possibly through 840 liesegang-type diffusion, forming layers of OM mixed with oxidised (e.g. phosphate and 841 carbonate) or reduced products (e.g. pyrite and ferric-ferrous minerals). Authigenic apatite 842 occurs as granules and is usually associated with OM, which often preserves microfossil 843 morphologies or patterned networks. Pyrite or haematite can also replace OM in microfossils, 844 and anatase and rutile occur as diagenetic phases associated with concentric rims or among 845 microfossils. The proposed chemically-oscillating reactions likely significantly contribute to 846 the preservation and degradation of microfossils, analogously to animal and plant fossils 847 being often present in concretions. We conclude that these late Paleoproterozoic microfossils 848 from the Lake Superior area were variably preserved because of the local and pore water 849 abundances of ferrihydrite, phosphate, sulphate, oxygen, and other oxidants (i.e. possibly 850 bromate). Future work will investigate trace bromine and sulphate concentrations in accessory 852 minerals. Additionally, experiments utilising naturally-occurring microbial remains and 
853

854

various siliceous gels containing ferric iron or phosphate need to investigate the range of possible reactants and concentrations for chemically-oscillating reactions under standard or diagenetic conditions. This new theory of putrefaction after the GOE, suggests that diagenetic spheroids should be more abundant in late Palaeoproterozoic rocks and predicts that these processes and objects should not be restricted to the Lake Superior area and may occur worldwide in contemporary rocks. Diagenetic spheroids can thus be regarded as mineral fractal patterns precipitated from chemically-oscillating reactions, which creates characteristic patterns around decaying dead organisms, over several scale dimensions.

Our new model provides many new hypotheses to test: 1) B-Z type processes can produce rosettes and granules in cherts and phosphorites which should contain diagenetic carbonate and phosphate minerals, 2) microfossil remains of $\mathrm{OM}$ in chert should be preserved, perhaps rarely, in granules including in Paleoarchean cherts (e.g. Schopf and Kudryavtsev, 2012), 3) jaspers with concretions and granules should occasionally contain haematitic microfossils, and since the Eoarchean (Dodd et al., 2017), and 4) phosphate-rich rocks may contain metabolically-diverse microbial ecosystems variably-preserved in apatite concretions, granules, and rosettes. Notably, microfossils are often concentrated within granules and associated with a range of diagenetic mineral products, which represents a robust petrologic context to conclude on the biological origin of candidate microfossils and thus a promising model to resolve past controversies on their biogenecity. These conclusions and predictions are thus highly relevant to the debates on evidence of Paleoarchean and Eoarchean life, and they augment the repertoire of biosignatures to search for fossil extraterrestrial life.

\section{Acknowledgements}

DP acknowledges financial support from the London Centre for Nanotechnology, University College London, Carnegie Institution for Science, NASA Astrobiology Institute 
879 (grant \# NNA04CC09A), the NASA Exobiology and Evolutionary Biology Program (grant \# 880 NNX08A016G), NASA Early Career Fellowship Program, Carnegie of Canada, and the W.M. 881 Keck Foundation. ZS acknowledges financial support from National Natural Science 882 Foundation of China (grant \# 41272038) and State Key Laboratory of Biogeology and 883 Environmental Geology, China University of Geosciences (grant \# GBL11610). DP also thanks 884 Melanie Humphrey for access to drill cores, W. Cannon for advice on outcrop location and 885 access, Ahmed Aibak for assistance in the field and core library, Philip Fralick, Richard 886 Ojakangas, and Hiroshi Ohmoto for organising field trips to some of the visited localities, and 887 S. Mojzsis for providing Gunflint sample GF-7. STXM data was acquired at the Advanced Light 888 Source, which is supported by the Director, Office of Science, Office of Basic Energy Sciences, 889 of the U.S. Department of Energy (under Contract No. DE-AC02-05CH11231) and David D.A. 890 Kilcoyne is thank for assistance with these analyses. Constructive criticism by Marc Norman, 891 Paul Strother, Bevan French, and two anonymous reviewers contributed to improve this 892 manuscript.

\section{References}

896 Alexander, C.M.O’D., Fogel, M., Yabuta, H., and Cody, G.D. (2007) The origin and evolution of chondrites recorded in the elemental and isotopic compositions of their macromolecular organic matter. Geochimica et Cosmochimica Acta 71, 4380-4403.

899 Alléon, J., Bernard, S., Le Guillou, C., Marin-Carbonne, J., Pont, S., Beyssac, O., McKeegan, K., and Robert, F. (2016) Molecular preservation of 1.88 Ga Gunflint organic microfossils as a function of temperature and mineralogy. Nature Communications, DOI: 10.1038/ncomms11977. 
903

904

905

906

907

908

909

910

911

912

913

914

915

916

917

918

919

920

921

922

923

924

925

926

927

928

Amstaetter, K., Borch, T., and Kappler, A. (2012) Influence of humic acid imposed changes of ferrihydrite aggregation on microbial Fe(III) reduction. Geochimica et Cosmochimica Acta 85, 326-341.

Awramik, S.M. and Barghoorn, E.S. (1977) The Gunflint microbiota. Precambrian Research 5, 121-142.

Bailey, J.V., Joye, S.B., Kalanetra, K.M., Flood, B.E. and Corsetti, F.A. (2007) Evidence of giant sulphur bacteria in Neoproterozoic phosphorites. Nature 445, 198-201.

Barge, L.M., Cardoso, S.S.S., Cartwright, J.H.E., Doloboff, I.J., Flores, E., Macias-Sanchez, E., SainzDiaz, C. I., and Sobron, P. (2016) Self-assembling iron oxyhydroxide/oxide tubular structures.: laboratory-grown and field examples from Rio Tinto. Proc. R. Soc. A 472, 20160466, 1-19.

Barghoorn, E.S. and Tyler, S.A. (1965) Microorganisms from the Gunflint Chert. Science 147, 563-577.

Bentor, Y.K. (1980) Phosphorites - The unresovled problems. SEPM Special Publication No. 29,

$$
\text { 3-18. }
$$

Benzerrara, K., Skouri-Panet, F., Li, Ferard, C., Gugger, M., Laurent, T., Couradeau, E., Ragon, M., Cosmidis, J., Menguy, N., Margaret-Oliver, I., Tavera, R., Lopez-Garcia, P., and Moreira, D. (2014) Intracellular Ca-carbonate biomineralization is widespread in cyanobacteria. P.N.A.S. 111, 10933-10938.

Bernard, S., Wirth, R., Schreiber, A., Schulz, H.-M., and Horsfield, B. (2012) Formation of nanoporous pyrobitumen residues during maturation of the Barnett Shale (Fort Worth Basin). International Journal of Coal Geology 103, 3-11.

Bernard, S., Benzerara, K., Beyssac, O., Brown, G.E., Grauvogel Stamm, L., and Duringer, P. (2009) Ultrastructural and chemical study of modern and fossil sporoderms by Scanning Transmission Y-ray Microscopy (STXM). Review of Palaeobotany and Palynology 156, 248-261. 
929 Bernard, S., Benzerara, K., Beyssac, O., Menguy, N., Guyot, F., Brown, G.E., and Goffe, B. (2007) 930 Exceptional preservation of fossil plant spores in high-pressure metamorphic rocks. $931 \quad$ Earth and Planetary Science Letters 262, 257-272.

932 Beyssac, O., Goffe, B., Chopin, C., and Rouzaud, J.N. (2002) Raman spectra of carbonaceous 933 material in metasediments: a new geothermometer, J. Met. Geol. 20, 859- 871

934 Blake, R.E. O’Neil, J.R., and Garcia, G.A. (1998) Effects of microbial activity on the $\delta^{180}$ of 935 dissolved inorganic phosphate and textural feature of synthetic apatites. American Mineralogist 83, 1516-1531.

937 Boyce, C.K., Cody, G.D., Feser, M. (2002) Organic chemical differentiation within fossil plant

Boyd, T.D. and Scott, S.D. (2001) Microbial and hydrothermal aspects of ferric oxyhydroxides and ferrosic hydroxides: the example of Franklin Seamount, Western Woodlark Basin, Papua New Guinea. Geochemical Transactions 2, 45, doi:10.1039/b105277m.

Brasier, M.D., Antcliffe, J., Saunders, M., and Wacey, D. (2015) Changing the picture of Earth's earliest fossils (3.5-1.9 Ga) with new approaches and new discoveries. P. N. A. S. 112, 4859-4864.

Brehm, U., Krumbein, W.E., and Palinska, K.A. (2003) Microbial spheres: a novel cyanobacterial-diatom symbiosis. Naturwissenschaften $\mathbf{9 0 , 1 3 6 - 1 4 0 .}$

Buick, R. (1992) The antiquity of oxygenic photosynthesis: evidence from stromatolites in sulphate-deficient Archean lakes. Science 255, 74-77.

Carrigan, W.J. and Cameron, E.M. (1991) Petrological and stable isotope studies of carbonate and sulfide minerals from the Gunflint Formation, Ontario: evidence for the origin of early Proterozoic iron-formation. Precambrian Research 52, 347-380.

Chauhan, D.S. (1979) Phosphate-bearing stromatolites of the Precambrian Aravalli phosphorite deposits of the Udaipur region, their environmental significance and genesis of phosphorite. Precambrian Research 8, 95-126. 
Cloud, P.E. and Licari, G.R. (1968) Microbiotas of the banded iron formations. P. N. A. S. 61, 779-786.

957 Cody, G.D., Heying, E., Alexander, C.M.O’D., Nittler, L.R., Kilcoyne, A.L.D., Sandford, S.A., and 19176.

961 cometary organic solids. Proceedings of the National Academy of Sciences 108, 19171-

Cody, G.D., Botto, R.E., Ade, H., and Wirick, S. (1996) The application of soft X-ray microscopy to the in-situ analysis of sporinite in coal. International Journal of Coal Geology 32, 6986.

Crosby, C.H., Bailey, J., and Sharma, M. (2014) Fossil evidence of iron-oxidizing chemolithotrophy linked to phosphogenesis in the wake of the Great Oxidation Event. Geology 42, 1015-1018.

Czaja, A.D., Beukes, N.J., and Osterhout, J.T. (2016) Sulfur-oxidising bacteria prior to the Great Oxidation Event from the 2.52 Ga Gamohaan Formation of South Africa. Geology 44, 983-986.

De Gregorio, B.T., Sharp, T.G., Flynn, G.J., Wirick, S., and Hervig, R.L. (2009) A biogenic origin for Earth's oldest putative microfossils. Geology 37, 631-634.

De Gregorio, B.T., Sharp, T.G., Rushdi, A.I., and Simoneit, B.R.T. (2011) Bugs or gunk? Nanoscale methods for assessing the biogenicity of ancient microfossils and organic matter. In: Golding, S.D., Glikson, M. (Eds.), Earliest Life on Earth: Habitats, Environments, and Methods of Detection, Springer, Dordrecht, Netherlands, 239-289.

Desmarais, D. (2001) Isotopic evolution of the biogeochemical carbon cycle during the Precambrian. Reviews in Mineralogy and Geochemistry 43, 555-578.

Dodd, M.S., Papineau, D., Grenne, T., Slack, J.F., Rittner, M., Pirajno, F., O’Neil, J., and Little, C.T.S. (2017) Evidence for early life in Earth's oldest hydrothermal vent precipitates. Nature 543, 60-64, DOI 10.1038/nature21377. 
981 Eigenbrode, J.L. and Freeman, K.H. (2006) Late Archean rise of aerobic microbial ecosystems. P.N.A.S. 103, 15759-15764.

983 Epstein, I.R. Kustin, K., De Kepper, P., and Orban, M. (1983) Oscillating Chemical Reactions. 984 985 Force, E.R. (1991) Geology of Titanium-Mineral Deposits. Geol. Soc. Am. Sp. Pap. 259, 112pp. 986 Fralick, P., Davis, D., and Kissin, S.A. (2002) The age of the Gunflint Formation, Ontario, Canada: single zircon $\mathrm{U}-\mathrm{Pb}$ age determinations from reworked volcanic ash. Canadian Journal of Earth Sciences 39, 1085-1091.

French, B.M. (1968) Progressive contact metamorphism of the Biwabik Iron-Formation Mesabi Range, Minnesota. Minnesota Geological Survey Bulletin 49, 103 p.

991 Fujishima, A. and Zhang, X. (2006) Titanium dioxide photocatalysis: present situation and future approaches. Comptes Rendus de Chimie 9, 750-760.

Garcia-Ruiz, J.M., Nakouzi, E., Kotopoulou, E., Tamborrino, L., and Steinbock, O. (2017)

Gribb, A.A., and Banfield, J.F. (1997) Particle size effects on transformation kinetics and phase stability in nanocrystalline $\mathrm{TiO}_{2}$. Am. Mineral. 82, 717-728. Biomimetic mineral self-organization from silica-rich spring waters. Science Advances

Gruner, J.W. (1946) Mineralogy and geology of the Mesabi Range. St. Paul, MN, Office of the 1001 Commissional of the Iron Range Resources and Rehabilitaton, 127 p.

Hayes, J.M. (1994) Global methanotrophy at the Archean-Proterozoic transition, In: Bengtson S. (Ed.) Nobel Symposium 84, Early life on Earth. Columbia University Press, New York, p. $220-236$

Heaman, L.M., Easton, R.M., Hart, T.R., Hollings, P., MacDonald, C.A., and Smyk, M., (2007) Further refinement of the timing of Mesoproterozoic magmatism, Lake Nipigon region, 
1008 Heaney, P.J. and Veblen, D.R. (1991) An examination of spherulitic dubiomicrofossils in

Precambrian banded iron formations using the transmission electron microscope. Precambrian Research 49, 355-372.

1011 Heimann, A., Johnson, C.M., Beard, B.L., Valley, J.W., Roden, E.E., Spicuzza, M.J., and Beukes, N.J.

Hiatt, E.E., Pufahl, P.K., and Edwards, C.T. (2015) Sedimentary and associated fossil bacteria in a Paleoproterozoic tidal flat in the 1.85 Ga Michigamme Formation, Michigan, USA. alkanes. J. Electron Spectrosc. Relat. Phenomena 42, 11-26. Sedimentary Geology 319, 24-39.

Hitchcock, A.P., and Ishii, I. (1987) Carbon K-shell excitation spectra of linear and branched

Hitchcock, A.P. and Biron, C.E. (1980) Inner-shell excitation of formaldehyde, acetaldehyde, and acetone studied by electron impact. Journal of Electron Spectroscopy and Related Phenomena 19, 231-250.

1023 Hofmann, H.J. (1972) Stromatolites: characteristics and utility. Earth Sciences Reviews 9, 339373.

1025 House, C.H., Schopf, J.W., and Stetter, K.O. (2003) Carbon isotopic fractionation by Archaeans 1026 and other thermophilic prokaryotes. Organic Geochemistry 34, 345-356.

1027 House, C.H., Schopf, J. W., McKeegan, K.D., Coath, C.D., Harrison, T.M., Stetter, K.O. (2000) Carbon isotopic composition of individual Precambrian microfossils. Geology 28, 7071030 Igisu, M., Ueno, Y., Shimojima, M., Nakashima, S., Awramik, S.M. Ohta, H., Maruyama. (2009) 1031 Micro-FTIR spectroscopic signature of bacterial lipids in Proterozoic microfossils. $1032 \quad$ Precambrian Research 173, 19-26. 
1033 Joosu, L., Lepland, A., Kirsimae, K., Romashkin, A.E., Roberts, N.M.W., Martin, A.P., and Crne, A. 1034 (2015) The REE-composition and petrography of apatite in 2 Ga Zaonega Formation, Russia: The environmental setting for phosphogenesis. Chemical Geology 395, 88-107.

1036 1037 1038

Juniper, S. K. \& Fouquet, Y. Filamentous iron-silica deposits from modern and ancient hydrothermal sites. Canadian Mineralogist 26, 859-869 (1988).

Karhu, J.A. and Holland, H.D. (1996) Carbon isotopes and the rise of atmospheric oxygen. Geology 24, 867-870.

Karkhanis, S. N. (1976) Fossil iron bacteria may be preserved in Precambrian ferroan carbonate. Nature 261, 406-407.

Kazmierczak, J. (1979) The Eukaryotic nature of Eosphaera-like ferriferous structures from the Precambrian Gunflint iron formation, Canada: A comparative study. Precambrian Research 9, 1-22.

Kilcoyne, A. L. D., Tyliszczak, T., Steele, W. F., Fakra, S., Hitchcock, P., Franck, K., Anderson, E., Harteneck, B., Rightor, E. G., Mitchell, G. E., Hitchcock, A. P., Yang, L., Warwick, T., Ade, H. (2003). Interferometer-controlled scanning transmission X-ray microscopes at the Advanced Light Source, The Journal of Synchrotron Radiation 10, 125-136.

Knoll, A.H. and Simonson, B. (1981) Early Proterozoic microfossils and penecontemporaneous quartz cementation in the Sokoman Iron Formation, Canada. Science 211, 478-480.

Knoll, A.H. and Barghoorn, E.S. (1975) Precambrian Eukaryote organisms: a reassessment of the evidence. Science 190, 52-54.

Köhler, I., Konhauser, K.O., Papineau, D., Bekker, A., and Kappler, A. (2013) Biological carbon precursor to diagenetic siderite spherulites in banded iron formations. Nature Communication 4:1741, 1-7.

Kouketsu, Y., Mizykami, T., Mori, H., Endo, S., Aoya, M., Hara, H., Nakamura, D., and Wallis, S., (2014) A new approach to develop the Raman carbonaceous material geothermometer for low-grade metamorphism using peak width. Island Arc 23, 33-50. 
1059 LaBerge, G.L. (1973) Possible biological origin of Precambrian Iron-Formations. Economic 1060 Geology 68, 1098-1109.

1061 LaBerge, G.L. (1967) Microfossils and Precambrian Iron-Formations. G.S.A. Bull. 78, 331-342.

1062 Lafhid, A., Beyssac, O., Deville, E., Negro, F., Chopin, C., and Goffe, B. (2010) Evolution of the 1063 Raman spectrum of carbonaceous material in low-grade metasediments of the Glarus 1064 Alps (Switzerland). Terra Nova 22, 354-360.

Lanier, W.P. (1989) Interstitial and peloid microfossils from the 2.0 Ga Gunflint Formation: 1066 Implications for the Paleoecology of the Gunflint stromatolites. Precambrian Research 45, 291-318.

Leith, C.K., (1903) The Mesabi iron-bearing district of Minnesota. U.S, Geological Survey Monograph 43, $316 \mathrm{pp}$.

Lepland, A., Joosu, L., Kirsimäe, K., Prave, A.R., Romashkkin, A.E., Crne, A., Martin, A.P., Fallick, A.E., Somelar, P., üpraus, K., Mänd, K., Roberts, N.M.W., van Zuilen, M.A., Wirth, R., Schreiber, A. (2013) Potential influence of Sulphur bacteria on Palaeoproterozoic phosphogenesis. Nature Geoscience, DOI: 10.1038/NGE02005.

Little, C. T. S., Glynn, S. E. J. \& Mills, R. A. (2004) Four-hundred-and-ninety-million-year record of bacteriogenic iron oxide precipitation at sea-floor hydrothermal vents. Geomicrobiol. J. 21, 415-429.

Lougheed, M.S. (1983) Origin of Precambrian iron-formation in the Lake Superior region. G.S.A. Bulletin 94, 325-340.

Maliva, R.G., Knoll, A.H., and Simonson, B.M. (2005) Secular change in the Precambrian silica cycle: insights from chert petrology. GSA Bulletin 117, 835-845.

Marshall, C.P., Emry, J.R., and Olcott Marshall, A. (2011) Haematite pseudomicrofossils present in the 3.5-billion-year-old Apex chert. Nature Geoscience DOI: 10.1038/NGE01084.

Marshall, C.P. and Olcott Marshall, A. (2013) Raman hyperspectral imaging of microfossils: potential pitfalls. Astrobiology 13, DOI: 10.1089/ast.2013.1034. 
1085 Moreau, J.W. and Sharp, T.G. (2004) A transmission electron microscopy study of silica and 1086 kerogen biosignatures in 1.9 Ga Gunflint microfossils. Astrobiology 4, 196-210.

1087 Mossman, D.J., Gauthier-Lafaye, F., and Jackson, S.E. (2005) Black shales, organic matter, ore 1088 1089 genesis and hydrocarbon generation in the Paleoproterozoic Franceville Series, Gabon. Precambrian Research 137, 253-272.

1090 Nelson, G.J., Pufahl, P.K., and Hiatt, E.E. (2010) Palaeoproterozoic constraints on Precambrian phosphorite accumulation, Baraga Group, Michigan, USA. Sedimentary Geology 226, 921.

Oehler, D.Z. (1976) Transmission electron microscopy of organic microfossils from the late 1094 Precambrian Bitter Springs Formation of Australia: techniques and survey of preserved ultrastructure. Journal of Paleontology 50, 90-106.

1096 Ojakangas, R.W., Marmo, J.S., and Heiskanen, K.I. (2001) Basin evolution of the 1097 Paleoproterozoic Karelian Supergroup of the Fennoscandian (Baltic) Shield. Sedimentology Geology 141-142, 255-285.

1099 Pacton, M., Ariztegui, D., Wacey, D., Kilburn, M.R., Rollion-Bard, C., Farah, R., and Vasconcelos, 1100 C. (2012) Going nano: a new step toward understanding the processes governing 1101 freshwater ooid formation. Geology 40, 547-550.

1102 Papineau, D., De Gregorio, B.T., Fearn, S., Kilcoyne, D., Purohit, R., and Fogel, M.L. (2016) 1103 Nanoscale petrographic and geochemical insights on the origin of Paleoproterozoic 1104 1105 stromatolitic phosphorites from Aravalli, India. Geobiology, DOI 10.1111/gbi12164. 1-

1106 Papineau, D., Purohit, R., Fogel, M.L., and Shields, G.A. (2013) High phosphate availability as a 1107 possible cause for massive cyanobacterial production of oxygen in the Proterozoic 1108 atmosphere. Earth and Planetary Science Letters 362, 225-236. 
1109 Papineau, D., DeGregorio, B.T., Cody, G.D., O'Neil, J., Steele, A., Stroud, R.M., and Fogel, M.L.

1110

1111

1112 1113

1114 (2011) Young poorly crystalline graphite in the >3.8 Gyr old Nuvvuagittuq banded iron formation, Nature Geoscience 4, 376-379.

Papineau, D. (2010) Global biogeochemical changes at both ends of the Proterozoic: Insights from phosphorites, Astrobiology 10, 1-17.

Papineau, D., Mojzsis, S.J., Coath, C.D., Karhu, J.A. and McKeegan, K.D. (2005) Multiple sulfur isotopes of sulfide from sediments in the aftermath of Paleoproterozoic glaciations. Geochim. Cosmochim. Acta 69, 5033-5060.

Rasmussen, B., Fletcher, I.R., Bekker, A., Muhling, J.R., Gregory, C.J., and Thorne, A.M. (2012) Deposition of 1,88-billion-year-old iron formations as a consequence of rapid crustal growth. Nature 484, 498-501.

Ruttenberg, K.C. (2005) The global phosphorus cycle. In: Treatise on Geochemistry, Elsevier, ISBN: 0-08-0443-43-5, pp 585-643.

Schidlowski, M. (2001) Carbon isotopes as biogeochemical recorders of life over 3.8 Ga of Earth history: Evolution of a concept. Precambrian Research 106, 117-134.

Schneider, D.A, Bickford, M.E., Cannon, W.F., Schulz, K.J., and Hamilton, M.A. (2002) Age of volcanic rocks and syndepositional iron formations, Marquette Range Supergroup: implications for the tectonic setting of Paleoproterozoic iron formations of the Lake Superior region. Can. J. Earth Sci. 39, 999-1012.

Schopf , J.W., Kudryavtsev, A.B., Walter, M.R., van Kranendonk, M.J., Williford, K.H., Kozdon, R., Valley, J., Gallardo, V.A., Espinoza, C., and Flannery, D.T. (2015) Sulfur-cycling fossil bacteria from the 1.8-Ga Duck Creek Formation provide promising evidence of evolution's null hypothesis. P.N.A.S. DOI: 10.1073/pnas.1419241112.

Schopf, J.W. and Kudryavtsev, A.B. (2012) Biogenecity of Earth's earliest fossils: A resolution of the controversy. Gondwana Research 22, 761-771. 
1134 Schopf, J.W., Kudryavtsev, A.B., Agresti, D.G., Czaja, A.D., and Wdowiak, T.J. (2006) Raman imagery: a new approach to assess the chemical maturity and biogenicity of permineralized Precambrian fossils. Astrobiology 5, 333-371.

Schopf, J.W. (1993) Microfossils of the Early Archean Apex Chert: Evidence of the antiquity of life. Science 260, 640-646.

Schulz, H.N. and Schulz, H.D. (2005) Large sulfur bacteria and the formation of phosphorite. Science 307, 416-418.

Schulz, K.J. and Cannon, W.F. (2007) The Penokean orogeny in the Lake Superior region. Precambrian Research 157, 4-25.

Shapiro, R.S. and Konhauser, K.O. (2015) Haematite-coated microfossils: primary ecological fingerprint or taphonomic oddity of the Paleoproterozoic? Geobiology 13, 209-224.

She, Z., Strother, P., and Papineau, D. (2014) Terminal Proterozoic cyanobacterial blooms and phosphogenesis documented by the Doushantuo granular phosphorites II: petrology and carbon isotopes. Precambrian Research 251, 62-79.

She, Z., Strother, P., McMahon, G., Nittler, L.R., Wang, J., Zhang, J., Longkang, S., Ma, C., and Papineau, D. (2013) Terminal Proterozoic cyanobacterial blooms and phosphogenesis documented by the Doushantuo granular phosphorites I: In situ micro-analyses of textures and composition. Precambrian Research 235, 20-35.

Simonson, B.M. (1985) Sedimentology of cherts in the Early Proterozoic Wishart Formation, Quebec-Newfoundland, Canada. Sedimentology 32, 23-40.

Sommers, M.G., Awramik, S.M., and Woo, K.S. (2000) Evidence for initial calcite-aragonite composition of lower algal chert member ooids and stromatolites, Paleoproterozoic Gunflint Formation, Ontario, Canada. Canadian Journal of Earth Sciences 37, 12291243.

Strauss, H. and Moore, T. B. (1992) Abundances and isotopic compositions of carbon and sulfur species in whole rock and kerogen samples. In The Proterozoic Biosphere, a 
multidisciplinary study (eds. J. W. Schopf and C. Klein). Cambridge Univ. Press, Cambridge, pp. 709-798.

1162 Sun, S., Chan, L.S., Y.L. Li (2014) Flower-like apatite recording microbial processes through deep geological time and its implication to the search for mineral records of life on Mars. American Mineralogist 99, 2116-2125.

Tyler, S.A. and Barghoorn, E.S. (1954) Occurrences of structurally preserved plants in preCambrian rocks of the Canadian Shield. Science 119, 606-609

1167 Van Cappellen, P. and Berner, R.A. (1991) Fluorapatite crystal growth from modified seawater 1168 solutions, Geochimica et Cosmochimica Acta 55, 1219-1234.

1169 Vanag, V. and Epstein, I.R. (2003) Segmented spiral waves in a reaction-diffusion system. P.N.A.S. 25, 14635-14638.

1171 Vandenbroucke, M. and Largeau, C. (2007) Kerogen origin, evolution and structure. Organic 1172 Geochemistry 38, 719-833.

1173 Van Wyck, N. and Johnson, C.M. (1997) Common lead, Sm-Nd, and U-Pb constraints on petrogenesis, crustal architecture and tectonic setting of the Penokean orogeny (Paleoproterozoic) in Wisconsin. GSA Bulletin 109, 799-808.

Wacey, D., Menon, S., Green, L., Gerstmann, D., Kong, C., McLoughlin, N., Saunders, M., and Brasier, M. (2012) Taphonomy of very ancient microfossils from the 3400Ma Strelley

Wacey, D., McLoughlin, N., Kilburn, M.R., Saunders, M., Cliff, J.B., and Kong, C. (2013) Nanoscale analysis of pyritised microfossils reveals differential heterotrophic consumption in the 1.9 Ga Gunflint chert. P. N. A. S. 110, 8020-8024. compounds. Annual Reviews of Microbiology 61, 379-400.

1185 Williford, K.H., Ushikubo, T., Schopf, J.W., Lepot, K., Kitajima, K., and Valley, J.W. (2013) 
Preservation and detection of microstructural and taxonomic correlations in the carbon isotopic compositions of individual Precambrian microfossils. Geochimica et Cosmochimica Acta 104, 165-182.

1189 Winter, B.L. and Knauth, L.P. (1992) Stable isotope geochemistry of cherts and carbonates from the 2.0 Ga Gunflint iron formation: implications for the depositional setting, and the effects of diagenesis and metamorphism. Precambrian Research 59, 283-313.

1192 Zaikin, A.N. and Zhabotinsky, A.M. (1970) Concentration wave propagation in twodimensional liquid-phase self-oscillating system. Nature 225, 535-537.

- Table 1: Stable isotope data of rocks from MMTU drill core from Michigamme Fm.

- Table 2: Energy Dispersive Spectroscopy-based compositional analyses of selected minerals in the Michigamme and Biwabik Formations.

- Table 3: Stable isotope data of rocks from MMTU drill core (Michigan Technical University).

- Table 4: Summary table of the main new observations for the three types of chert studied in this work. 
Table 1: Raman band parameters for best fit with linear combinations of Lorentz functions.

\begin{tabular}{|c|c|c|c|c|c|c|}
\hline $\begin{array}{l}\text { Lorentz- } \\
\text { fitted } \\
\text { parameters }\end{array}$ & $\begin{array}{c}\text { GF-7 } \\
\text { coccoidal } \\
\text { microfossil }\end{array}$ & $\begin{array}{c}\text { GF-7 } \\
\text { filamentous } \\
\text { microfossil }\end{array}$ & $\begin{array}{l}\text { ME-B1 } \\
\text { large } \\
\text { coccoids }\end{array}$ & $\begin{array}{c}\text { MaryEllen-1 } \\
\text { coccoid } \\
\text { granule }\end{array}$ & $\begin{array}{c}\text { MA0708 } \\
\text { coccoidal } \\
\text { microfossil }\end{array}$ & $\begin{array}{l}\text { MA0708 } \\
\text { filamentous } \\
\text { microfossil }\end{array}$ \\
\hline G pos & 1590 & 1590 & 1575 & 1595 & 1586 & 1587 \\
\hline G fwhm & 43 & 43 & 60 & 60 & 33 & 39 \\
\hline G area & 2000 & 2250 & 2900 & 1800 & 2400 & 7900 \\
\hline D1 pos & 1340 & 1342 & 1346 & 1337 & 1352 & 1349 \\
\hline D1 FWHM & 95 & 130 & 120 & 110 & 37 & 44 \\
\hline D1 area & 17000 & 18000 & 5000 & 4500 & 3200 & 14700 \\
\hline D2 pos & 1615 & 1615 & 1620 & 1620 & 1620 & 1620 \\
\hline D2 FWHM & 40 & 40 & 40 & 35 & 25 & 25 \\
\hline D2 area & 8200 & 7000 & 580 & 600 & 350 & 1500 \\
\hline D3 pos & 1510 & 1510 & 1510 & 1510 & & \\
\hline D3 FWHM & 200 & 100 & 135 & 135 & & \\
\hline D3 area & 6500 & 2200 & 2200 & 1200 & & \\
\hline D4 pos & 1245 & 1245 & 1245 & 1245 & & \\
\hline D4 FWHM & 160 & 100 & 160 & 150 & & \\
\hline D4 area & 7000 & 3500 & 2200 & 900 & & \\
\hline D5 pos & & & 1450 & 1450 & & \\
\hline D5 FWHM & & & 100 & 100 & & \\
\hline D5 area & & & 450 & 500 & & \\
\hline $\begin{array}{l}\text { Temperature } \\
\text { Lafhid RA1 } \\
\text { Temparture }\end{array}$ & 267 & 346 & 229 & 280 & & \\
\hline $\begin{array}{l}\text { Beyssac } \\
\text { Temperature }\end{array}$ & 243 & 245 & 359 & 323 & 387 & 352 \\
\hline Kuketsu & 274 & 199 & 220 & 242 & 398 & 383 \\
\hline $\begin{array}{l}\text { average of } \\
\text { estimates }\end{array}$ & 261 & 263 & 269 & 282 & 393 & 367 \\
\hline 1 sigma & 16 & 75 & 78 & 41 & 8 & 23 \\
\hline
\end{tabular}

Temperature estimates are calculated according to calibrated geothermometres from Beyssac et al. (2002), Lafhid et al. (2010), and Kouketsu et al. (2015). Note that the Beyssac thermometer was not calibrated for crystallization temperatures below $350^{\circ} \mathrm{C}$. 
Table 2: Carbonates analyses by EDS in ME-B1 and of phosphates analysed by WDS in MA0708

\begin{tabular}{|c|c|c|c|c|c|c|c|}
\hline Targets & ME-B1 & ME-B1 & ME-B1 & MA0708 & MA0708 & MA0708 & MA0708 \\
\hline Wt.(\%) & spot 1a & spot 2a & spot $3 a$ & spot 1f & spot 1h & spot 11 & spot $3 a$ \\
\hline C K & 12.0 & 4.4 & 4.9 & & & & \\
\hline O K & 36.9 & 19.8 & 19.4 & 39.7 & 39.9 & 39.5 & 39.5 \\
\hline P K & & 9.9 & 10.3 & 18.0 & 18.2 & 17.8 & 17.8 \\
\hline Mg K & 1.4 & & & & & & \\
\hline Ca K & 2.6 & & & 39.0 & 39.0 & 39.4 & 39.4 \\
\hline Si K & 1.7 & 3.5 & 2.0 & 0.1 & 0.0 & 0.1 & 0.0 \\
\hline F K & 5.6 & & & 3.9 & 3.5 & 4.1 & 4.0 \\
\hline Mn K & 21.0 & & & & & & \\
\hline Fe K & 18.8 & 6.5 & 3.6 & & & & \\
\hline $\mathrm{Ni} \mathrm{K}$ & & 4.8 & 5.7 & & & & \\
\hline La L & & 12.3 & 14.9 & & & & \\
\hline Ce L & & 20.6 & 22.3 & & 0.2 & 0.1 & 0.1 \\
\hline Nd L & & 9.2 & 7.9 & & & & \\
\hline Sm L & & 4.3 & 4.6 & & & & \\
\hline Gd L & & 4.8 & 4.4 & & & & \\
\hline Y L & & & & & 0.1 & & 0.1 \\
\hline Totals & 100.0 & 100.1 & 100.0 & 100.7 & 100.8 & 100.9 & 101.0 \\
\hline & Mn-siderite & Monazite & Monazite & Fluorapatite & Fluorapatite & Fluorapatite & Fluorapatite \\
\hline
\end{tabular}


Table 3: Stable isotope data of rocks from MMTU drill core (Michigan Technical University).

\begin{tabular}{|c|c|c|c|c|c|c|c|c|}
\hline Identifier** & position (m) & $\delta^{13} \mathbf{C}_{\text {carb }}$ & err. & $\delta^{18} O_{\text {carb-smow }}$ & $\delta^{18} O_{\text {carb-PDB }}$ & err. & $\delta^{13} \mathbf{C}_{\text {org }}$ & TOC (wt\%) \\
\hline $\begin{array}{c}\text { MMTU-4.40 } \\
\text { MMTU-4.5 }\end{array}$ & $\begin{array}{l}1.3 \\
1.4\end{array}$ & & & & & & $\begin{array}{l}-23.8 \\
-28 .\end{array}$ & 0.49 \\
\hline MMTU-5.69 & $\begin{array}{l}1.4 \\
1.7\end{array}$ & & & & & & $\begin{array}{l}-28.0 \\
-23.2\end{array}$ & 0.23 \\
\hline MMTU-5.75 & 1.8 & -4.6 & 0.1 & $\begin{array}{r}+19.1 \\
+1\end{array}$ & -11.6 & 0.2 & -22.4 & 0.84 \\
\hline $\begin{array}{l}\text { MMTU-6. } 25 \\
\text { MMTH } 6 .\end{array}$ & 1.9 & & & & & & -33.6 & 0.50 \\
\hline $\begin{array}{l}\text { MMTUU-6.6 } \\
\text { MMTU-7.3 }\end{array}$ & $\begin{array}{l}2.0 \\
2.2\end{array}$ & & & & & & $\begin{array}{l}-22.9 \\
-23.5\end{array}$ & $\begin{array}{l}0.38 \\
0.65\end{array}$ \\
\hline MMTU-8.6 & 2.6 & -2.8 & 0.2 & +20.5 & -10.2 & 0.3 & -23.9 & 0.24 \\
\hline $\begin{array}{l}\text { MMTU-9.5 } \\
\text { MMTU-10.8 }\end{array}$ & $\begin{array}{l}2.9 \\
3.3\end{array}$ & -3.1 & 0.0 & +19.0 & -11.8 & 0.1 & $\begin{array}{l}-25.5 \\
-208\end{array}$ & $\begin{array}{l}0.57 \\
0.35\end{array}$ \\
\hline MMTU-11.6 & $\begin{array}{l}3.3 . \\
3.5 \\
3\end{array}$ & -4.3 & 0.2 & +15.6 & -15.1 & 0.3 & $\begin{array}{l}-20.8 \\
-46.7 \\
\end{array}$ & $\begin{array}{l}0.35 \\
0.21\end{array}$ \\
\hline $\begin{array}{l}\text { MMTU-12.3 } \\
\text { MMTU-1.87 }\end{array}$ & $\begin{array}{l}3.7 \\
4.2\end{array}$ & -3.3 & 0.2 & +137. & -16. & 0.3 & $\begin{array}{l}-25.4 \\
-25.2\end{array}$ & $\begin{array}{l}0.25 \\
0.24\end{array}$ \\
\hline & & $\begin{array}{l}-3.3 \\
-1.5\end{array}$ & $\begin{array}{l}0.2 \\
0.1\end{array}$ & $\begin{array}{l}+13.7 \\
+13.9\end{array}$ & $\begin{array}{l}-16.8 \\
-16.7\end{array}$ & $\begin{array}{l}0.3 \\
0.3\end{array}$ & $\begin{array}{l}-25.2 \\
-25.0\end{array}$ & $\begin{array}{l}0.24 \\
0.32\end{array}$ \\
\hline MMTU-18.4 & $\begin{array}{l}5.4 \\
5.6\end{array}$ & $\begin{array}{l}-1.5 \\
-2.8 \\
-1.5\end{array}$ & 0.2 & $\begin{array}{l}+13.9 \\
+13.6\end{array}$ & $\begin{array}{l}-16.9 \\
-16.9\end{array}$ & 0.3 & $\begin{array}{l}-23.7 \\
-23.7\end{array}$ & $\begin{array}{l}0.32 \\
0.10\end{array}$ \\
\hline MMTU-20.5 & 6.2 & -4.7 & 0.2 & +13.5 & -17.1 & 0.3 & -26.8 & 0.48 \\
\hline $\begin{array}{l}\text { MMTU-21.59 } \\
\text { MTU-257 }\end{array}$ & 6.6 & & & & & & $\begin{array}{l}-31.8 \\
-264\end{array}$ & 0.84 \\
\hline $\begin{array}{l}\text { MMMUU-25.7. } \\
\text { MMTU-28.2 }\end{array}$ & $\begin{array}{l}7.8 \\
8.6\end{array}$ & -2.2 & 0.1 & +14.4 & -16.2 & 0.1 & $\begin{array}{l}-26.4 \\
-33.4\end{array}$ & $\begin{array}{l}0.16 \\
0.45\end{array}$ \\
\hline MMTU-32.7 & 10.0 & & & & & & -29.1 & 0.38 \\
\hline $\begin{array}{l}\text { MMTU-38.0 } \\
\text { MMTU-40.0 }\end{array}$ & $\begin{array}{l}11.6 \\
12.2\end{array}$ & -5.2 & 0.2 & +10.8 & -19.7 & 0.2 & $\begin{array}{l}-24.4 \\
-29.1\end{array}$ & $\begin{array}{l}0.16 \\
0.55\end{array}$ \\
\hline MMTU-42.1 & $\begin{array}{l}12.2 \\
12.8\end{array}$ & -2.9 & 0.1 & +14.5 & -16.1 & 0.5 & $\begin{array}{l}-29.1 \\
-24.1\end{array}$ & $\begin{array}{l}0.55 \\
0.18\end{array}$ \\
\hline MMTU-44.0 & $\begin{array}{l}12.8 \\
13.4\end{array}$ & -2.9 & 0.1 & +14.5 & -16.1 & 0.5 & $\begin{array}{l}-24.4 \\
-29.4\end{array}$ & 0.31 \\
\hline $\begin{array}{l}\text { MMTU-45.9 } \\
\text { MMT-486 }\end{array}$ & $\begin{array}{l}14.0 \\
148\end{array}$ & & & & & & $\begin{array}{l}-25.6 \\
-240\end{array}$ & $\begin{array}{l}0.31 \\
0.10\end{array}$ \\
\hline $\begin{array}{l}\text { MMTU-48.6 } \\
\text { MMTU-5.3 }\end{array}$ & $\begin{array}{l}14.8 \\
159\end{array}$ & & & & & & $\begin{array}{l}-24.0 \\
-26.9\end{array}$ & 0.10 \\
\hline 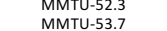 & $\begin{array}{l}15.9 \\
16.4\end{array}$ & $\begin{array}{l}-3.1 \\
-3.7\end{array}$ & $\begin{array}{l}0.5 \\
0.1\end{array}$ & $\begin{array}{l}+14.9 \\
+13.7\end{array}$ & $\begin{array}{l}-15 . / \\
-16.9\end{array}$ & $\begin{array}{l}u_{0} .3 \\
0 .\end{array}$ & 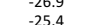 & $\begin{array}{l}1.24 \\
0.36\end{array}$ \\
\hline MMTU-60.0 & $\begin{array}{l}10.4 \\
18.3\end{array}$ & & 0.1 & +13.1 & -10.9 & & -26.4 & $\begin{array}{l}0.36 \\
1.38\end{array}$ \\
\hline MMTU-61.7 & $\begin{array}{l}18.8 \\
18 .\end{array}$ & & & & & & $\begin{array}{l}-27.2 \\
\text { - }\end{array}$ & $\begin{array}{l}1.40 \\
0.44\end{array}$ \\
\hline MMTU- 63.3 & 19.3 & -2.8 & 0.1 & +15.4 & -15.2 & 0.2 & -28.4 & 0.41 \\
\hline MMTU-66.1 & 20.1 & & & & & & -28.0 & 0.37 \\
\hline $\begin{array}{l}\text { MMTU-69.2 } \\
\text { MMTU-71.5 }\end{array}$ & $\begin{array}{l}21.1 \\
21.1 \\
21 .\end{array}$ & & & & & & $\begin{array}{l}-25.1 \\
-232\end{array}$ & 1.45 \\
\hline MMTU-74.6 & $\begin{array}{l}21.8 \\
22.7\end{array}$ & & & & & & $\begin{array}{l}-23.9 \\
-28.9\end{array}$ & $\begin{array}{l}0.27 \\
0.62\end{array}$ \\
\hline MMTU-75.8 & 23.1 & -3.3 & 0.2 & $\begin{array}{l}+13.0 \\
+14.2 \\
\end{array}$ & $\begin{array}{l}-10.0 \\
-16.4\end{array}$ & 0.2 & -24.5 & 0.67 \\
\hline MMTU-88.8 & 27.1 & & & +17.3 & & & -44.5 & 0.21 \\
\hline $\begin{array}{l}\text { MMTU-93.0 } \\
\text { MTU-93. }\end{array}$ & $\begin{array}{l}28.3 \\
285\end{array}$ & -1.4 & 0.2 & +15.0 & -15.6 & 0.2 & -23.3 & 0.30 \\
\hline $\begin{array}{l}\text { MMMT-93.6 } \\
\text { MMTU-949 }\end{array}$ & $\begin{array}{l}28.5 \\
28.9\end{array}$ & -2.0 & 0.2 & +15.3 & -15.3 & 0.2 & $\begin{array}{l}-23.2 \\
-21.5\end{array}$ & $\begin{array}{l}0.40 \\
0.05\end{array}$ \\
\hline $\begin{array}{l}\text { MMMUT-94.9.9 } \\
\text { MMTU-96.0 }\end{array}$ & $\begin{array}{l}28.9 \\
29.3\end{array}$ & & & +13.4 & & & $\begin{array}{l}-21.5 \\
-20.9\end{array}$ & $\begin{array}{l}0.05 \\
0.10\end{array}$ \\
\hline MMTU-97.2 & 29.6 & & & & & & -21.2 & 0.19 \\
\hline MMTU-100.0 & 30.5 & -2.5 & 0.1 & +13.7 & -16.8 & 0.2 & -25.3 & 0.89 \\
\hline MMTU-102.0 & $\begin{array}{l}31.1 \\
31.6\end{array}$ & $\begin{array}{l}-3.2 \\
-2.5\end{array}$ & 0.2 & +13.3 & -17.3 & 0.3 & -25.1 & 0.99 \\
\hline MMTU-105.1 & $\begin{array}{l}31.6 \\
32.0\end{array}$ & $\begin{array}{l}-2.5 \\
-3.5\end{array}$ & $\begin{array}{l}0.1 \\
0.2\end{array}$ & $\begin{array}{l}\begin{array}{l}14.3 \\
+16.4\end{array} \\
+\end{array}$ & $\begin{array}{l}-16.3 \\
-14.2\end{array}$ & $\begin{array}{l}0.2 \\
0.1\end{array}$ & $\begin{array}{l}-23.3 \\
-25.0\end{array}$ & $\begin{array}{l}0.19 \\
1.35\end{array}$ \\
\hline $\begin{array}{l}\text { MMTUU-155.1 } \\
\text { MMT-106.7 }\end{array}$ & $\begin{array}{l}32.0 \\
32.5\end{array}$ & -3.5 & 0.2 & +16.4 & -14.2 & 0.1 & $\begin{array}{l}-25.0 \\
-27.4\end{array}$ & $\begin{array}{l}1.35 \\
0.26\end{array}$ \\
\hline MMTU-107.8 & 32.9 & -3.0 & 0.2 & +14.0 & & 0.2 & -26.5 & 0.30 \\
\hline MMTU-111.9 & 34.1 & -3.6 & 0.1 & +14.5 & -16.0 & 0.2 & -27.1 & 0.08 \\
\hline MMTU-115.8 & 35.3 & $\begin{array}{l}-3.4 \\
-3.6\end{array}$ & 0.0 & +11.8 & -18.5 & 0.2 & -22.3 & 0.19 \\
\hline $\begin{array}{l}\text { MMTUU-124.0 } \\
\text { MMTU-127.3 }\end{array}$ & $\begin{array}{l}38.0 \\
38.8\end{array}$ & -3.6 & 0.1 & +11.8 & -18.7 & 0.4 & $\begin{array}{l}-22.6 \\
-22.1\end{array}$ & $\begin{array}{l}0.16 \\
0.05\end{array}$ \\
\hline MMTU-129.5 & $\begin{array}{l}39.5 \\
39.5\end{array}$ & -1.5 & 0.1 & +14.4 & -16.1 & 0.2 & $\begin{array}{l}-23.4 \\
-22.4 \\
-12\end{array}$ & 0.12 \\
\hline & 39.6 & & 0.1 & & -16.6 & 0.1 & -25.3 & 1.23 \\
\hline \multirow{5}{*}{$\begin{array}{l}\text { MMTU-130.5 } \\
\text { MMTU-132.1 }\end{array}$} & 39.8 & -3.0 & 0.2 & +12.7 & -17.8 & 0.3 & -23.4 & 0.05 \\
\hline & 40.3 & & & & & & -30.4 & 0.08 \\
\hline & $\max$ & -1.4 & & +20.7 & -10.1 & & -20.8 & 1.4 \\
\hline & $\min$ & -5.2 & & +10.8 & -19.7 & & -46.7 & 0.0 \\
\hline & $\begin{array}{c}\text { average } \\
\text { stdev }\end{array}$ & $\begin{array}{l}-3.1 \\
0.9\end{array}$ & & $\begin{array}{l}+14.8 \\
2.3\end{array}$ & $\begin{array}{l}-15.8 \\
2.3\end{array}$ & & $\begin{array}{l}-26.2 \\
4.8\end{array}$ & $\begin{array}{l}0.4 \\
0.4\end{array}$ \\
\hline
\end{tabular}

* Sample name includes the depth (in feet, as originally measured) for each sample. 
Table 4: Summary table of observations for the mineralogically distinct cherts of the Lake Superior Area.

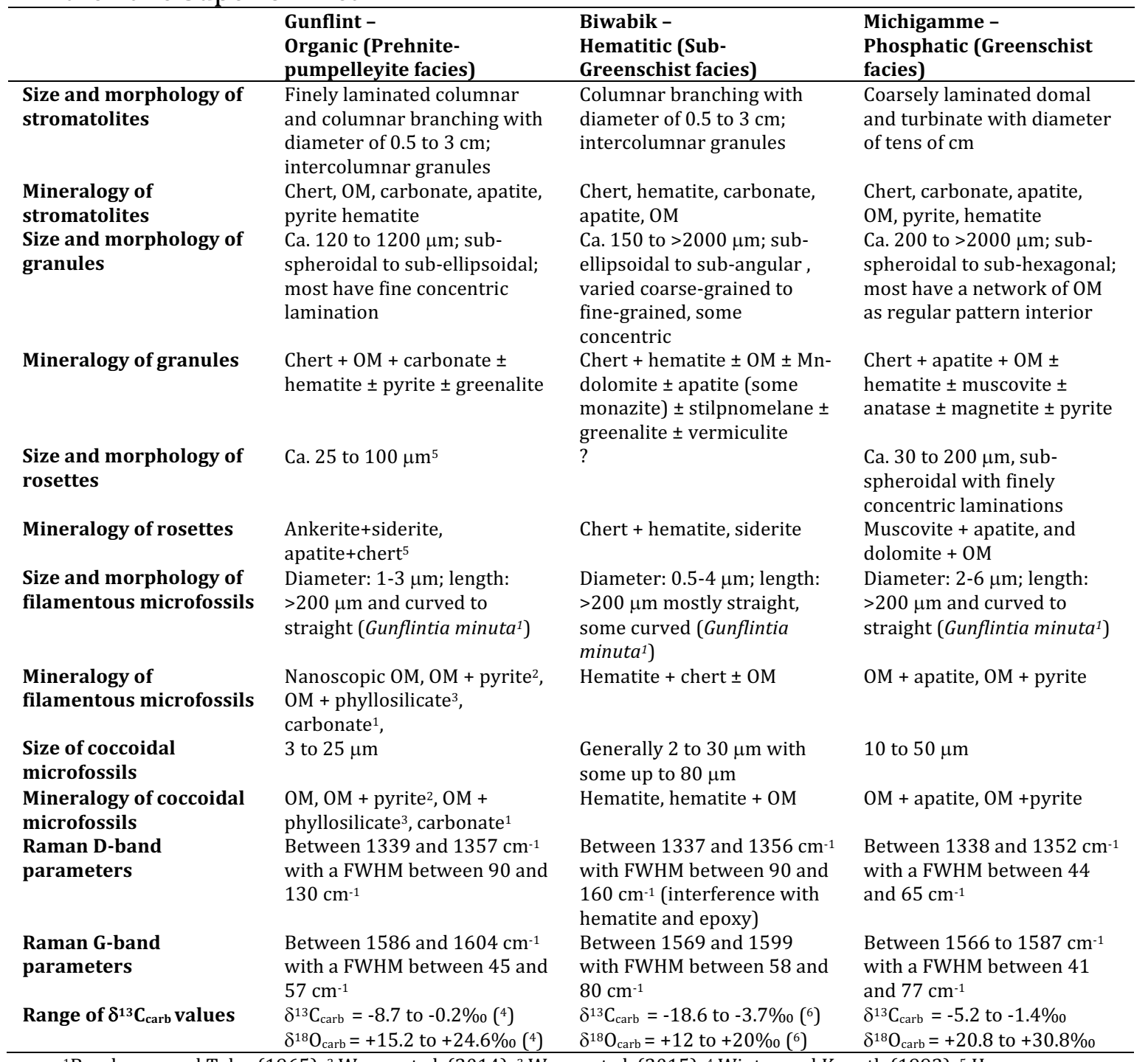

${ }^{1}$ Barghoorn and Tyler (1965), ${ }^{2}$ Wacey et al. (2014), ${ }^{3}$ Wacey et al. (2015), ${ }^{4}$ Winter and Knauth (1992), ${ }^{5}$ Heaney

and Veblen (1990), ${ }^{6}$ Perry et al., (1973). 


\section{Figure 1 - Papineau et al. (2017)}
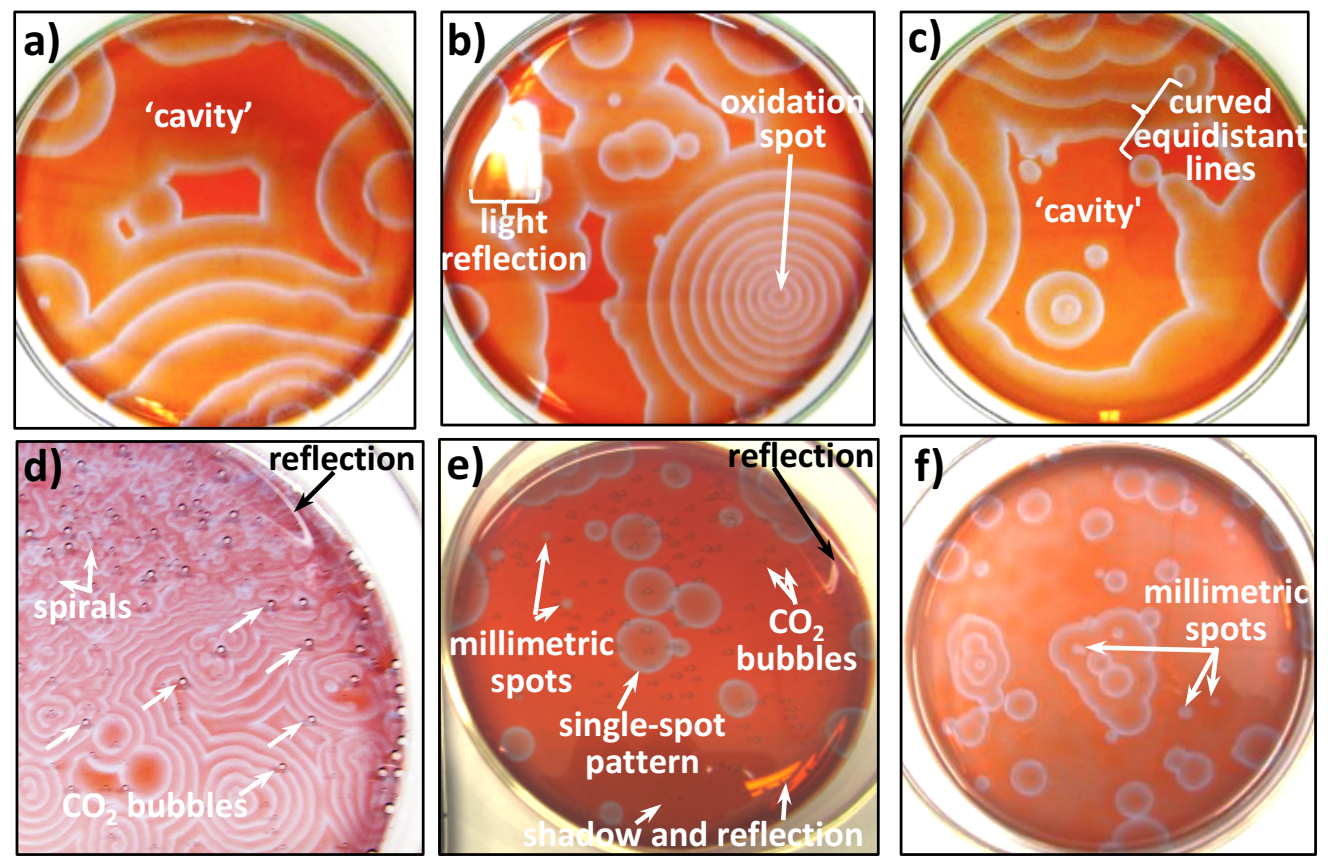

Figure 1: Reflected light images of different chemically-oscillating experiments performed with the same chemicals as in the classical Belousov-Zhabotinsky experiment $\left(6 \mathrm{ml}\right.$ of $\left\{67 \mathrm{ml}\left(\mathrm{H}_{2} \mathrm{O}+2 \mathrm{ml} \mathrm{H}_{2} \mathrm{SO}_{4}+5 \mathrm{~g} \mathrm{NaBrO}\right\}+0.5 \mathrm{ml}\right.$ of $\{1 \mathrm{~g} \mathrm{NaBr}+10$ $\mathrm{ml} \mathrm{H} \mathrm{H}_{2} \mathrm{O}+1 \mathrm{ml}$ of $\{1 \mathrm{~g}$ Malonic acid $+10 \mathrm{ml} \mathrm{H} 2 \mathrm{O}\}+1 \mathrm{ml}$ of $\{25 \mathrm{mM}$ pheanthroline ferrous sulphate (or Ferroin $(3 \mathrm{mM})-$ a coloured redox indicator $\}+0.5 \mathrm{ml}$ of $\{1 \mathrm{~g}$ Triton X-100 $+1000 \mathrm{ml} \mathrm{H}_{2} \mathrm{O}$ (to decrease surface tension)\}. a) Formation of a 'cavity' from oxidation spots along the edge of the Petri dish (10 cm diameter), b) formation of oxidation spots and concentric oxidation fronts with characteristic rounded equidistant lines, c) curved equidistant lines forming a 'cavity' that encloses concentric oxidation spots, d) rounded oxidation spots with finely equidistant oxidation fronts and $\mathrm{CO}_{2}$ bubble formation (white arrow), e) centimetre to millimetre-size single rounded spot pattern with $\mathrm{CO}_{2}$ bubbles, f) individual millimetre-size spots inside centimetre-size non-circular structures. 


\section{Figure 2 - Papineau et al. (2017)}
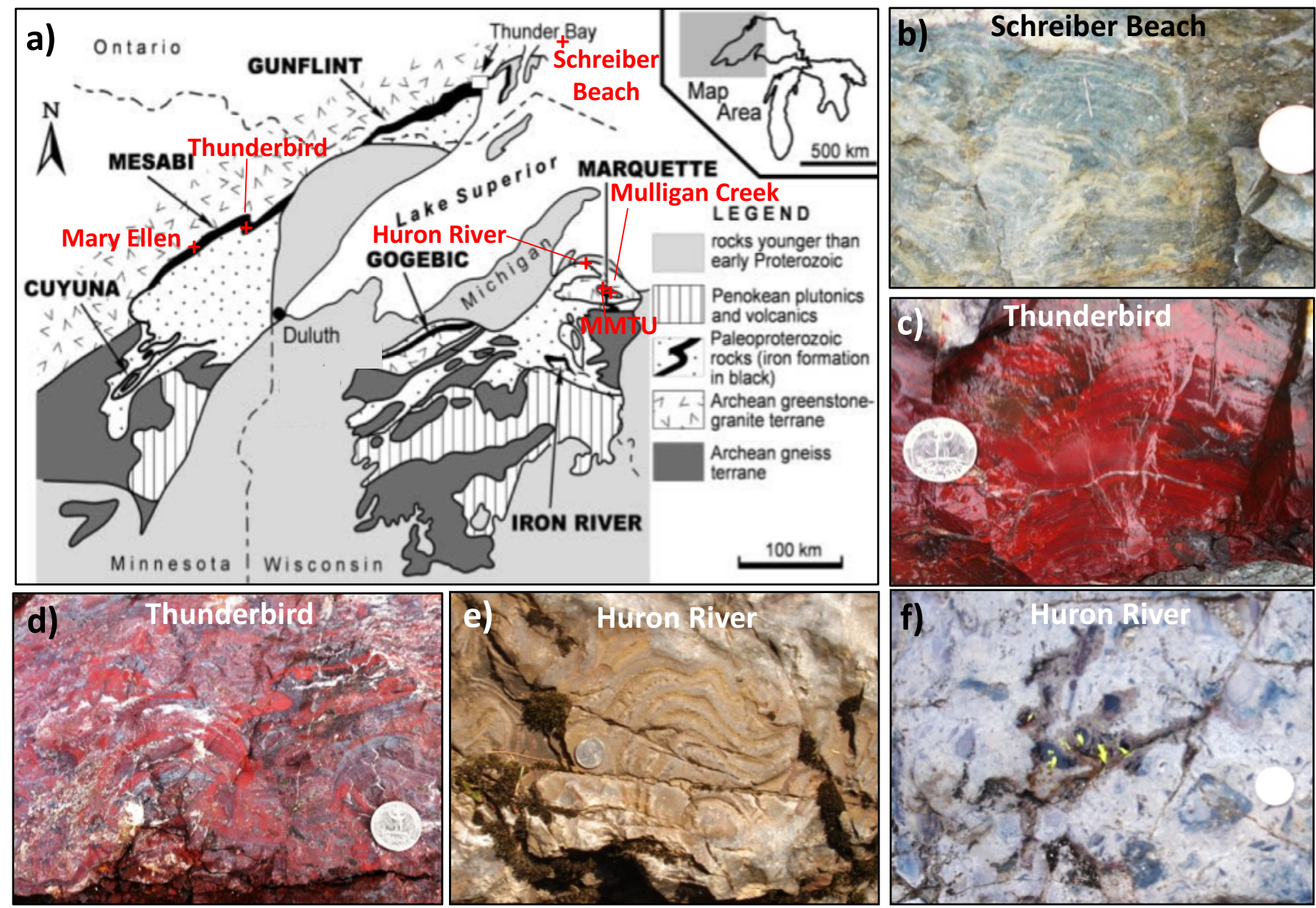

Figure 2: Geological context of the studied stromatolitic and concretionary cherts from the Gunflint, Biwabik, and Michigamme formations. a) regional geological map (modified from Pufhal and Fralick, 2004) showing the main iron ranges (bold) and the localities where samples from this study come from (red). Images of field outcrops of b) black chert from the Gunflint Fm. at the Schreiber Beach locality with centimeter-size columnar stromatolites, c) finely laminated columnar stromatolitic and granular jasper and d) bed of centimeter-size gray and red haematite-magnetite concretions with white carbonate patches in the Biwabik Fm., and e) coarse laminated decimeter-size cherty domal stromatolites and f) concretionary granular phosphatic chert stained yellow by ammonium molybdate from the Michigamme $\mathrm{Fm}$. at the Huron River locality. Coin diameter is $19 \mathrm{~mm}$ in b) and $24 \mathrm{~mm}$ in c-f). 


\section{Figure 3 - Papineau et al. (2017)}

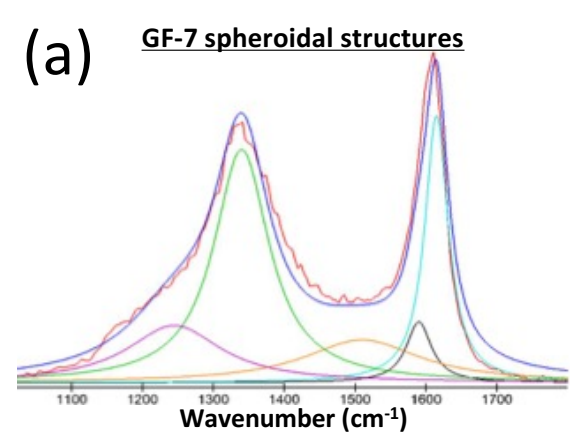

(b)

GF-7 filamentous structures

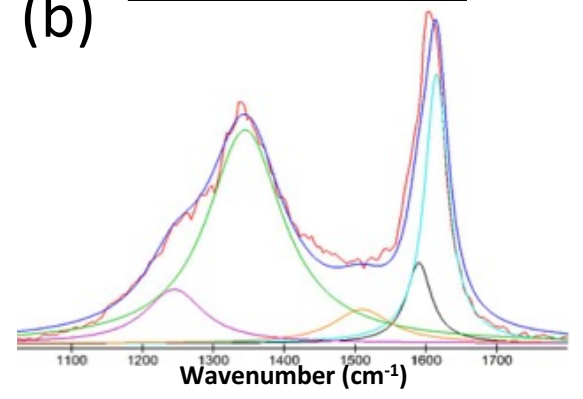

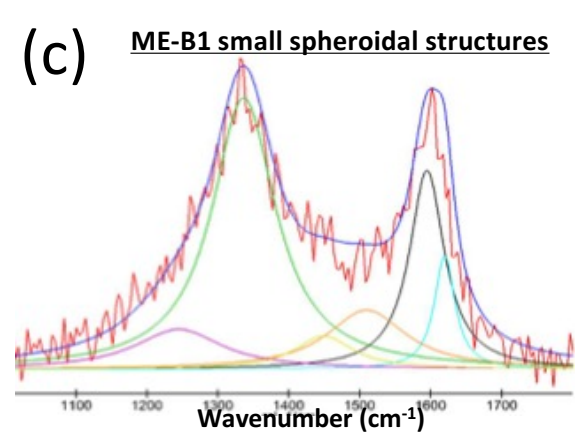

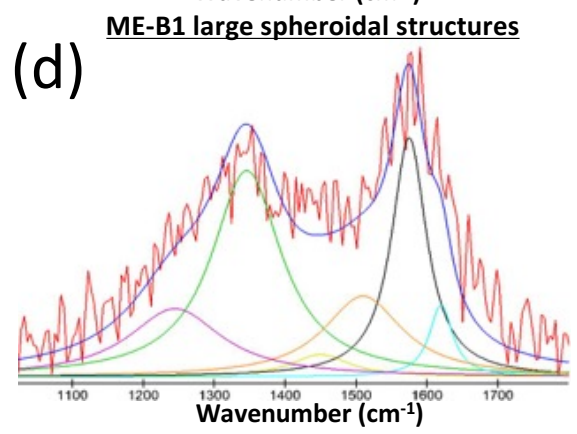

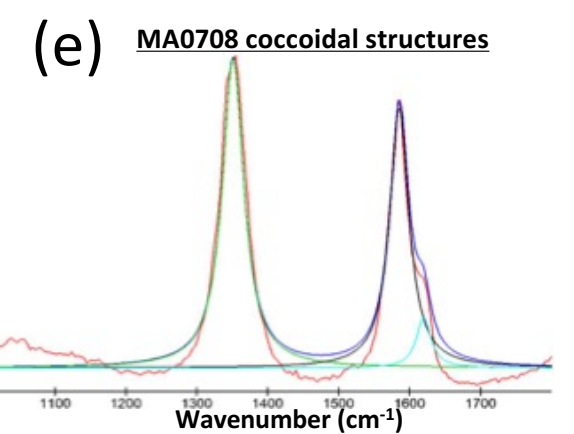

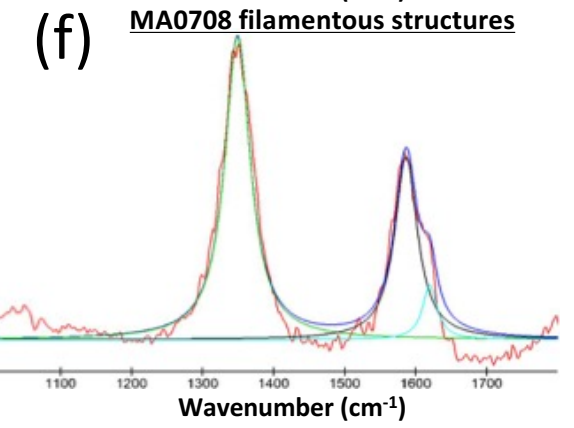

Figure 3: Measured (red) and modelled (blue) Raman spectra, after cosmic-ray reduction and polymonial-fitted background subtraction on OM from Gunflint, Biwabik, and Michigamme chert. Lorenz-fitted peaks are labelled in green (D1), turquoise (D2), orange (D3), purple (D4), yellow (D5), and black (G). Subsequent linear combination of lorenz-fitted D1, D2, D3, D4, D5, and G peaks is shown in blue - see calculated parameters in Table 1. 


\section{Figure 4 - Papineau et al. (2017)}
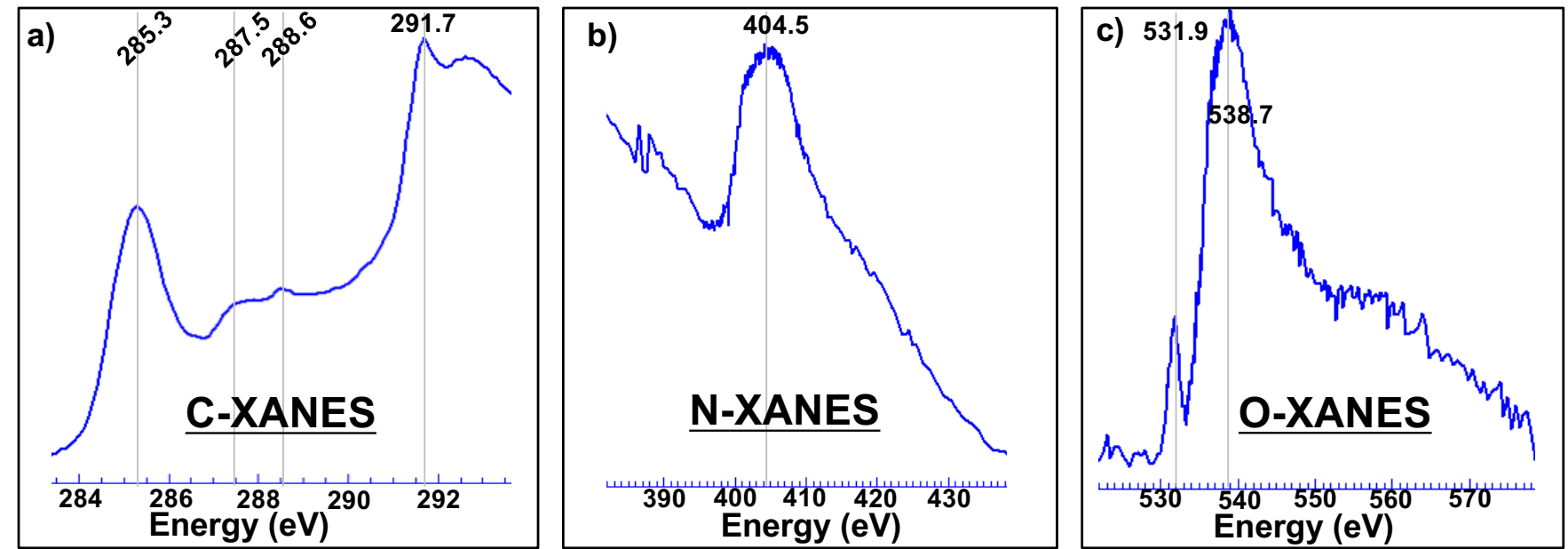

Figure 4: X-ray Absorption Near-Edge Structure spectra of acid-insoluble graphitic carbon from the Michigamme phosphatic chert MA0708. Spectrum in a) was acquired at C-edge and shows two strong peaks and two weak peaks, in b) shows a single weak peak at the $\mathrm{N}$-edge, and in $\mathrm{c}$ ) shows two peaks at the O-edge. The former XANES spectrum confirms the presence of carboxyl groups, while the latter two spectra confirm the presence of $\mathbf{N}$ and $\mathbf{O}$ functional groups in Michigamme graphitic carbon. 


\section{Figure 5 - Papineau et al. (2017)}
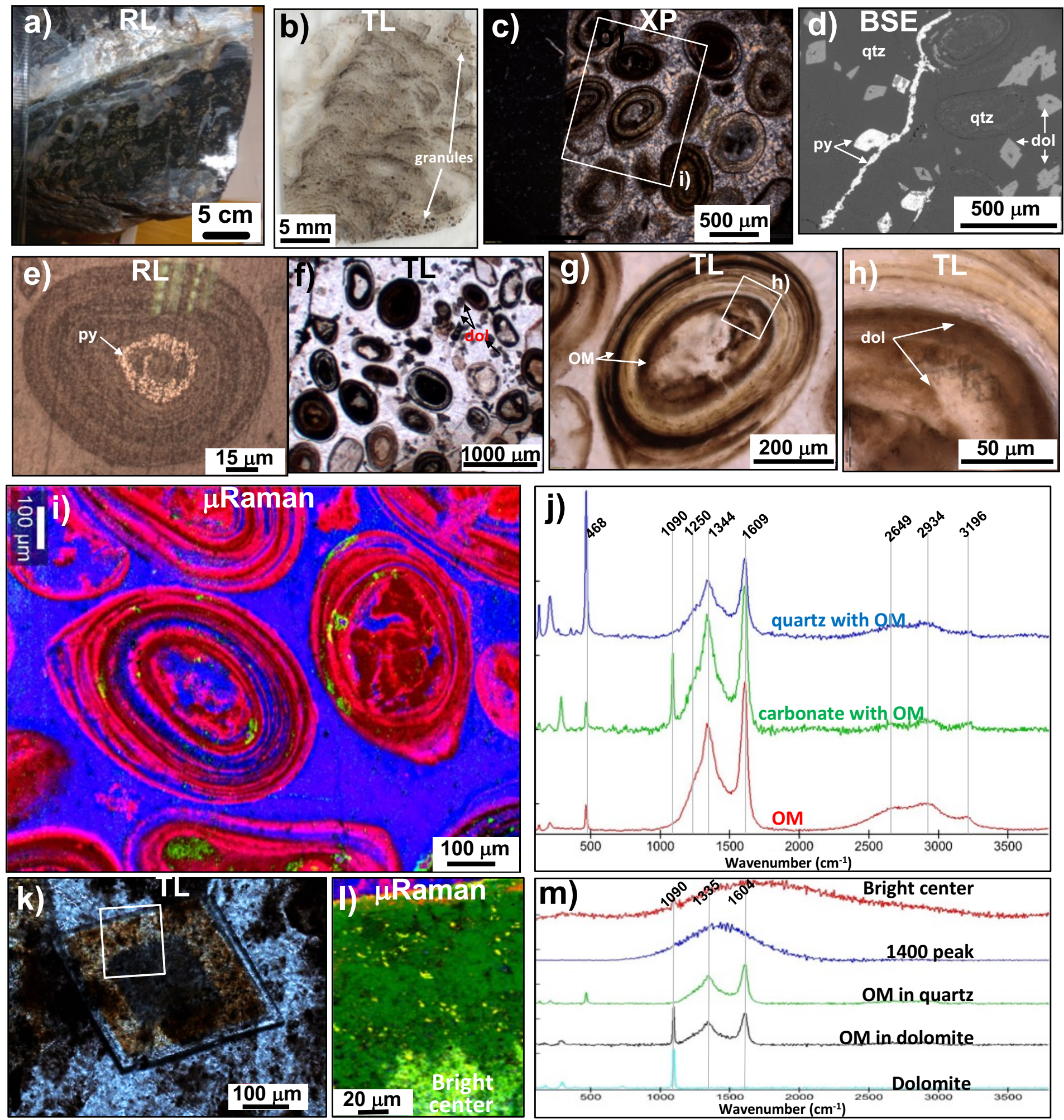

Figure 5: Petrography of stromatolitic and granular black chert sample GF-1 from the Gunflint Formation. a) A slab of the Gunflint cherty columnar stromatolite below white chert layer, b) granules between stromatolitic chert columns with finely laminated $\mathrm{OM}, \mathrm{c}$ ) concentrically-laminated granules, d) intergranular dolomite rhombs, some almost completely replaced by later pyrite, e) concentrically-laminated granule with a nucleus coated with a spheroidal pyrite layer, f) Granules with dispersed dolomite rhombs, g-h) granule with finely laminated OM associated with dolomite shown by arrows in (h), i) micro-Raman image of several granules with carbonate associated with OM layers, j) Raman spectra for the three phases in (i) and (I), $k-I)$ dolomite rhombohedron zoned with fluorescent $O M, m$ ) Raman spectra for dolomite rhomb. Raman colours here are the same for all subsequent figures: blue $=$ quartz, green $=$ carbonate, and red $=\mathrm{OM}$. Abbreviations: $\mathrm{BSE}=$ Back-Scattered Electron, $\mathrm{TL}=$ transmitted light, $\mathrm{CP}=$ crossed polars, $\mathrm{RL}=$ reflected light, $\mathrm{py}=$ pyrite, dol = dolomite, qtz = quartz, $\mathrm{OM}=$ organic matter. 


\section{Figure 6 - Papineau et al. (2017)}

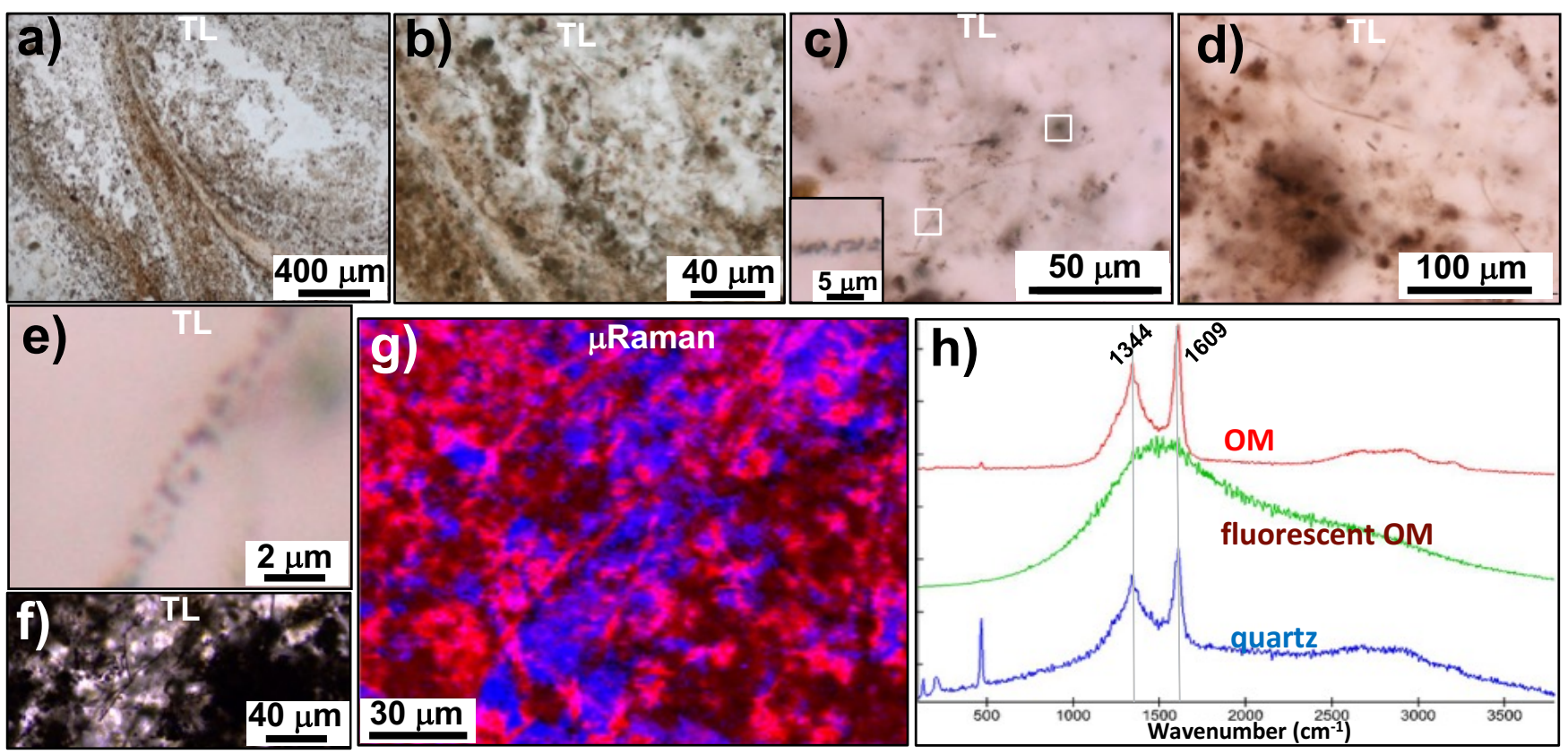

Figure 6: Petrography of filamentous structures composed of OM in black chert sample GF-1 from the Gunflint Formation. a-b) Stromatolite laminations with filamentous structures, c-e) filaments of $O M$ in the intercolumnar and intergranular matrix, $f$-g) filamentous structures composed of $O M$ inside a granule, $h$ ) Raman spectra of $\mathrm{OM}$ along with occasional fluorescent regions. 


\section{Figure 7 - Papineau et al. (2017)}

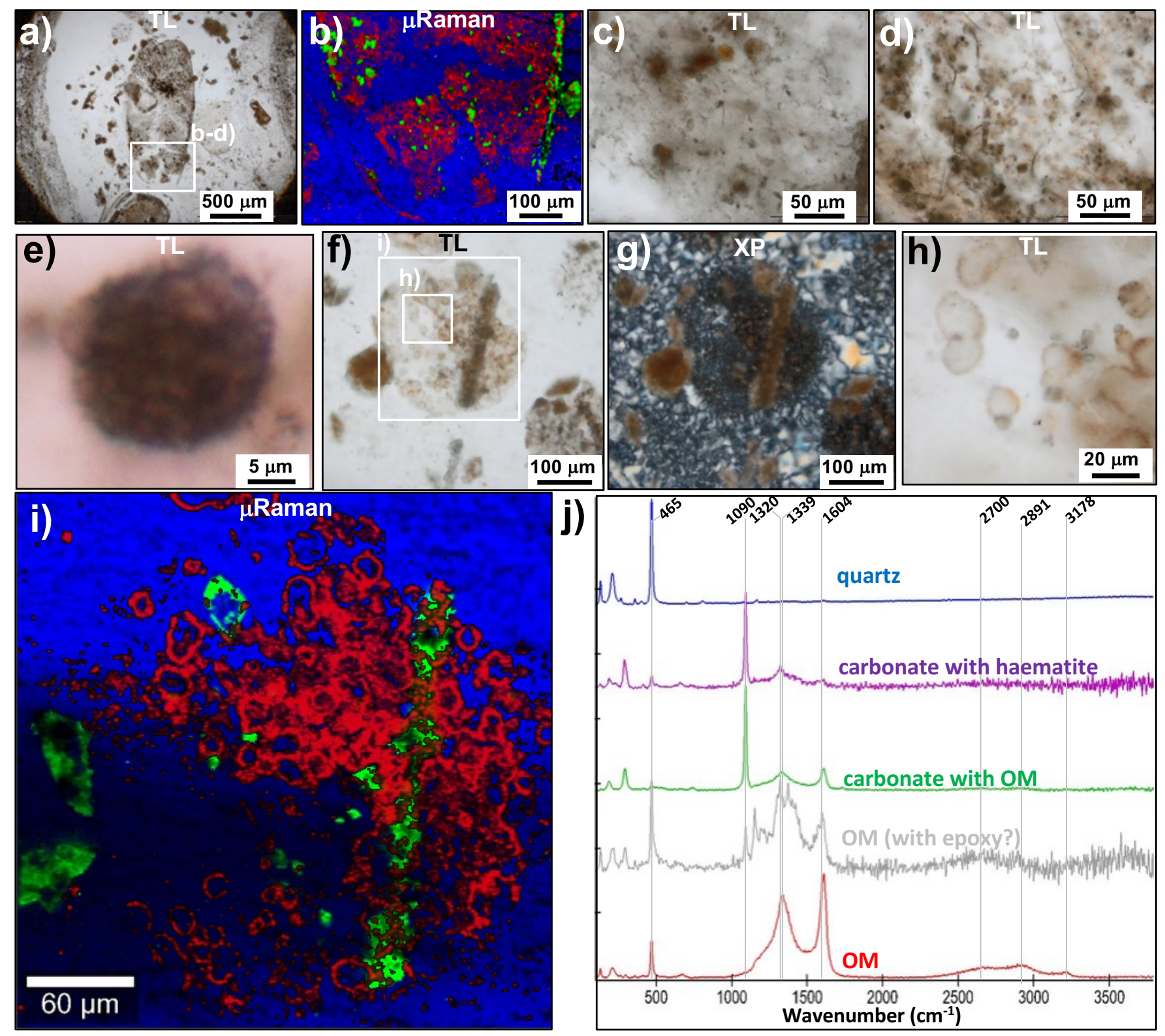

Figure 7: Examples of spheroidal structures in granules between columns of stromatolitic black chert from the Gunflint Fm (sample GF-7). a-c) granule with spheroidal and filamentous structures composed of OM, d) mixed spheroidal and filamentous structures in the chert matrix, e) spheroidal structure similar to Huroniospora macroreticulata in the matrix, $\mathrm{f}-\mathrm{h}$ ) granule with spheroidal structures and dolomite inside. i) Raman image of spheroidal structures composed of OM and carbonate in the granule in g), j) Raman spectra of the different phases in the Raman image. 


\section{Figure 8 - Papineau et al. (2017)}

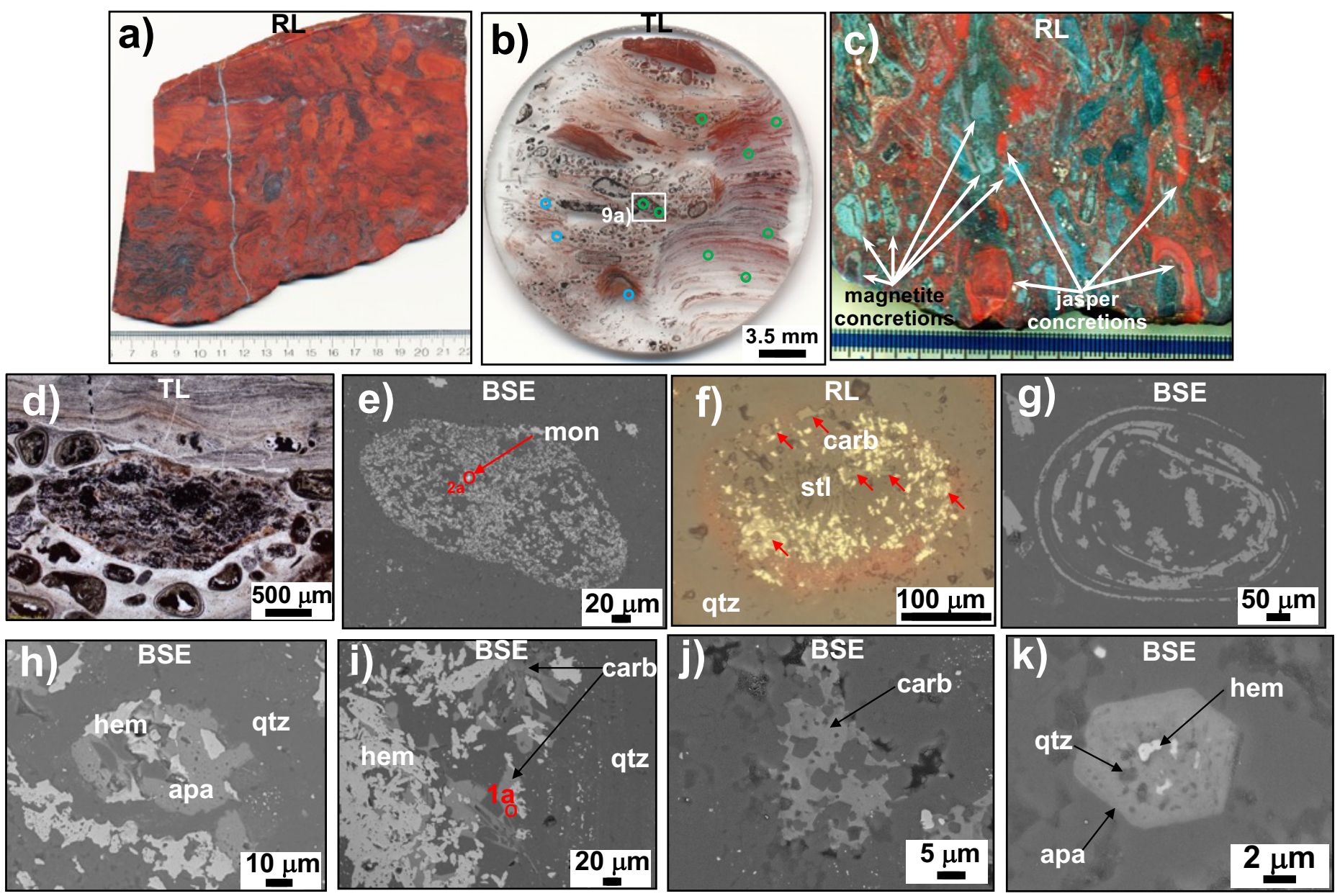

Figure 8: Petrography of stromatolitic and granular jasper from the Biwabik Fm (sample ME-B1 - Mary Ellen locality) in all panels except c-d, which are from sample AG1108 (Thunderbird locality). a) Polished slab of stromatolitic and granular jasper chert, b) thin section image of an area with intercolumnar granules and stromatolitic chert layered with microscopic red haematite showing the location of microscopic Mn-carbonate (blue circles) and apatite (green circles), c) polished slab of jasper with jasper and magnetite concretions, d) millimetre-size haematite-magnetite concretion amongst granules with fine internal disseminations of haematite forming wavy and spheroidal patterns, e) haematite granule with a grain of monazite, $f$ ) haematite granule with stilpnomelane core and anhedral carbonate (red arrows), g) haematite granule with fine concentric laminations, h) magnetite granule with blades of yellow-brown apatite, i) subhedral $\mathrm{Mn}$-siderite in a coarse-grained haematite granule, $\mathrm{j}$ ) anhedral $\mathrm{Mn}$-siderite with poikilitic texture, $\mathrm{k}$ ) euhedral apatite with nanoscopic inclusions of quartz and haematite inside a stromatolite column. Spot numbers (in red in panels e and $\mathrm{m}$ ) are for EDS analyses listed in Table 2. Abbreviations: mon = monazite, hem = haematite, qtz = quartz, carb = carbonate, apa $=$ apatite, stl $=$ stilpnomelane. 


\section{Figure 9 - Papineau et al. (2017)}
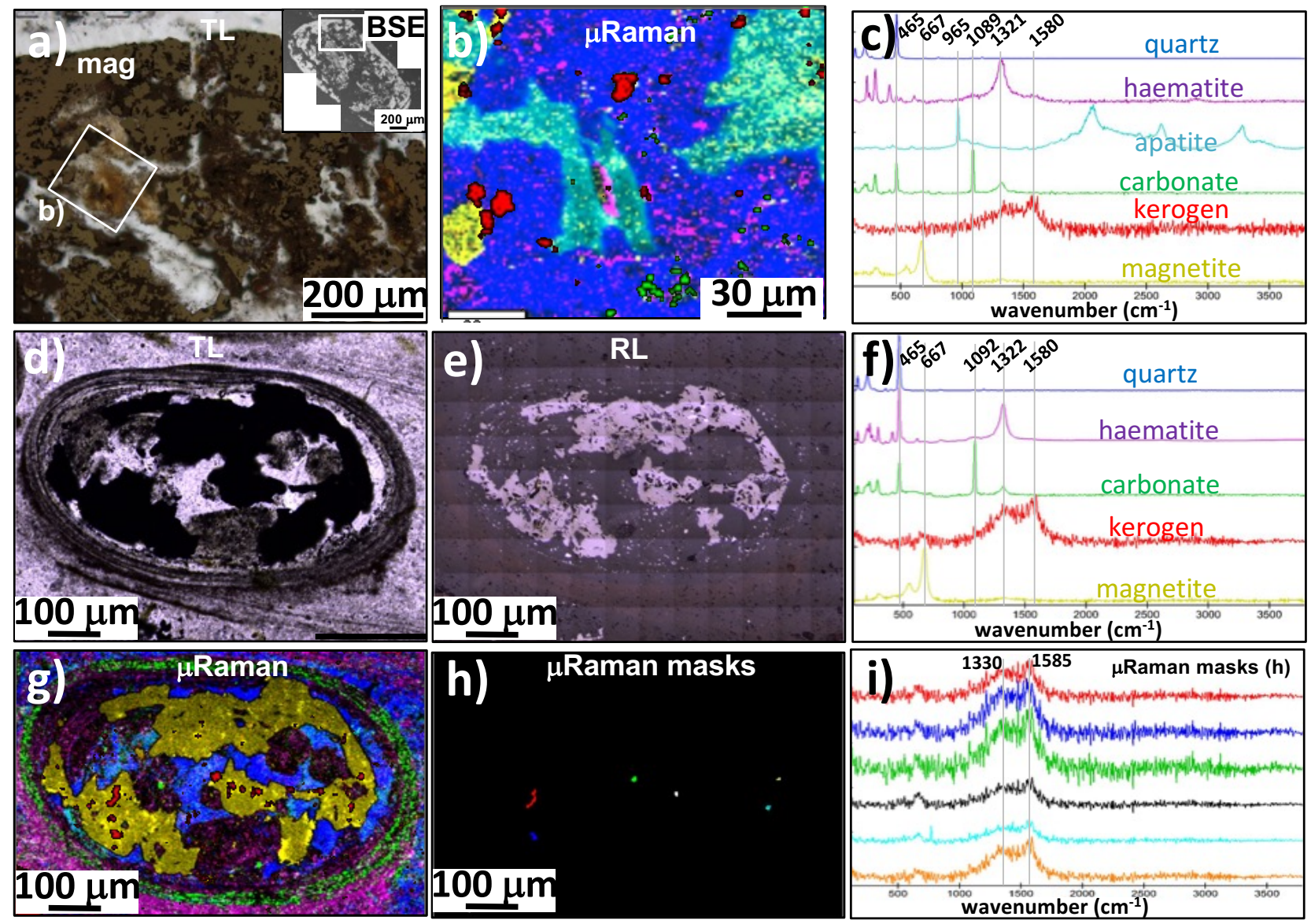

Figure 9: Detailed examples of occurrences of micron-size particles of OM in the Biwabik jasper-chert. (a-c) Apatite associated with carbonate and organic matter inside magnetite-haematite granule shown in inset. (d-g) Magnetite-haematite granule with coarse grained interior of quartz, magnetite, and haematite and with a rim of micron-size carbonate grains. ( $h-i)$ colour-coded masks corresponding to Raman image in (g) for micron-size particles of organic matter inside magnetite and related to their spectra in (i), most having low signal-to-noise ratio. Colours in Raman images are same as before along with yellow = magnetite, turquoise $=$ apatite , and purple $=$ haematite mag $=$ magnetite . 


\section{Figure 10 - Papineau et al. (2017)}
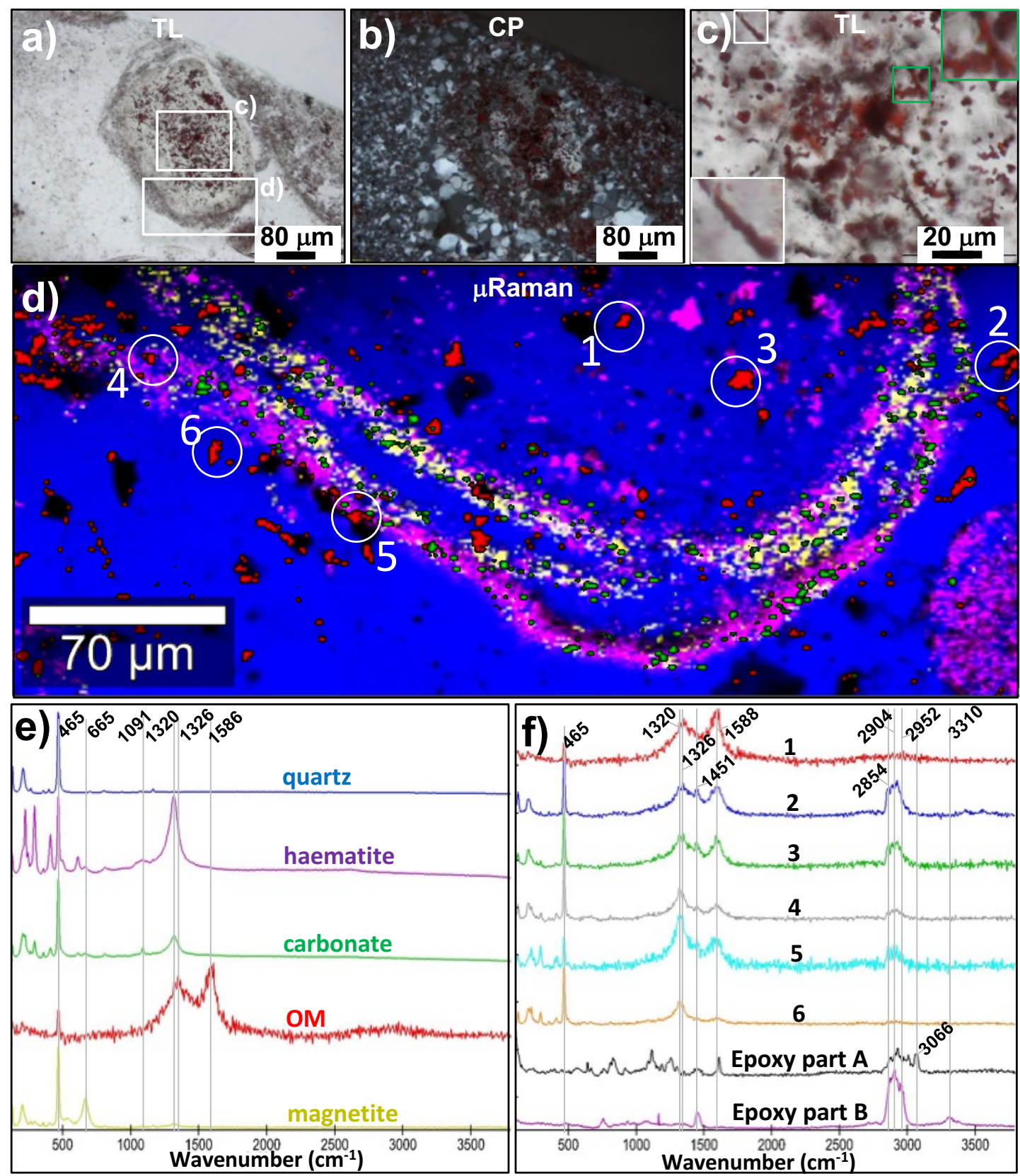

Figure 10: Filamentous structures in granular and stromatolitic jasper from the Biwabik Formation. a-c) Filamentous structures composed of haematite inside granules (with insets showing detailed view), d) Raman image of a section of the granule showing micron-size particles of OM, e) Raman spectra of the main minerals associated with this granule, f) diversity of Raman spectra for OM associated with haematite (numbers refer to OM particles circled in d). 


\section{Figure 11 - Papineau et al. (2017)}
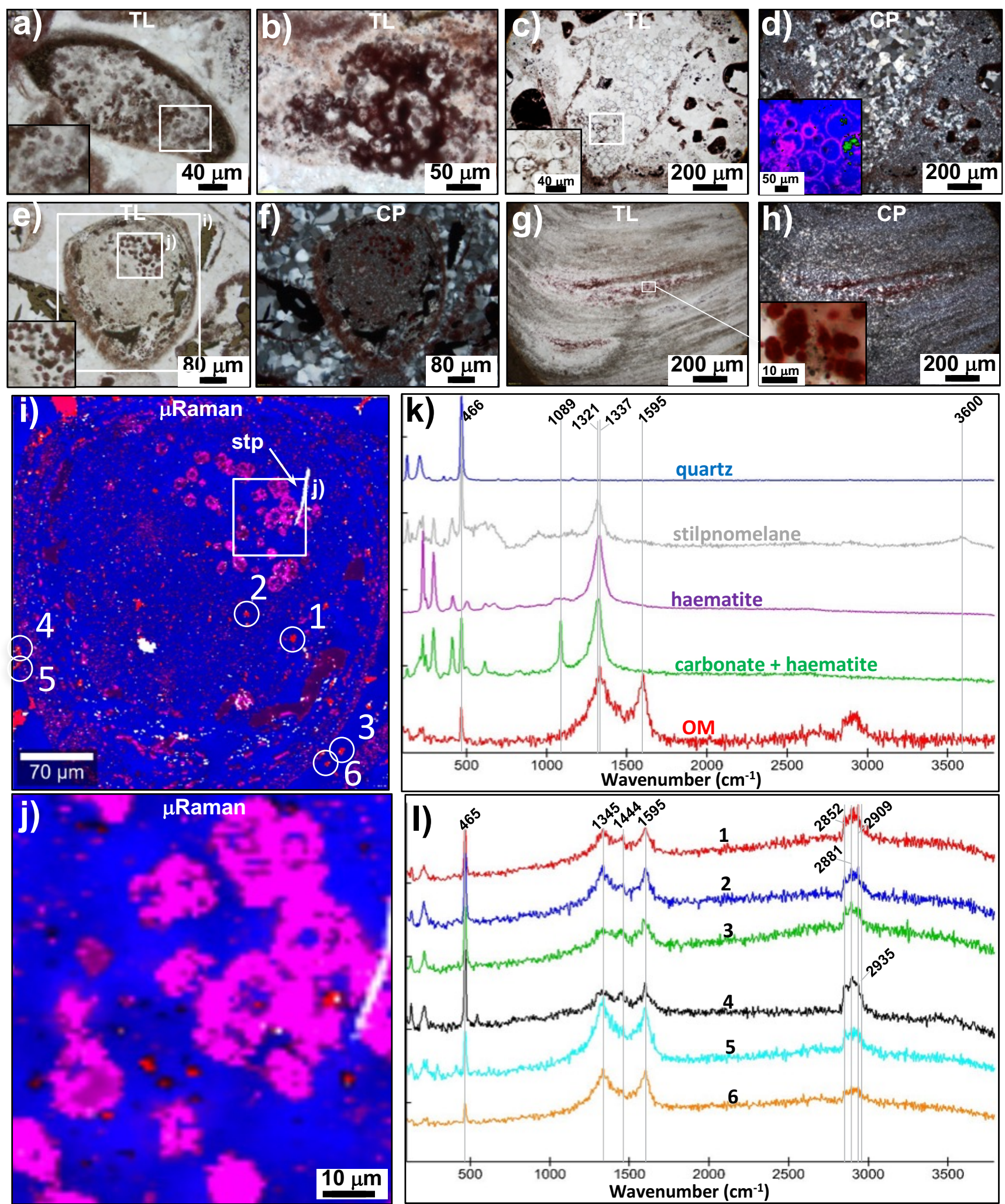

Figure 11: Spheroidal structures in granular and stromatolitic jasper from the Biwabik Formation. a-f) Spheroidal structures composed of haematite inside granules shown with zoomed-in insets, g) coarse grained chert interlayer in stromatolite column with micron-size spheroidal structures (shown in inset), i-j) Raman images of haematitic spheroidal microfossils associated with micron-size particles of OM, k) Raman spectra of the main minerals associated with spheroidal structures, i) range of Raman spectra for OM associated with haematite (numbers refer to those in i). colours in Raman image are same as in Fig. 9 with white = stilpnomelane. 


\section{Figure 12 - Papineau et al. (2017)}

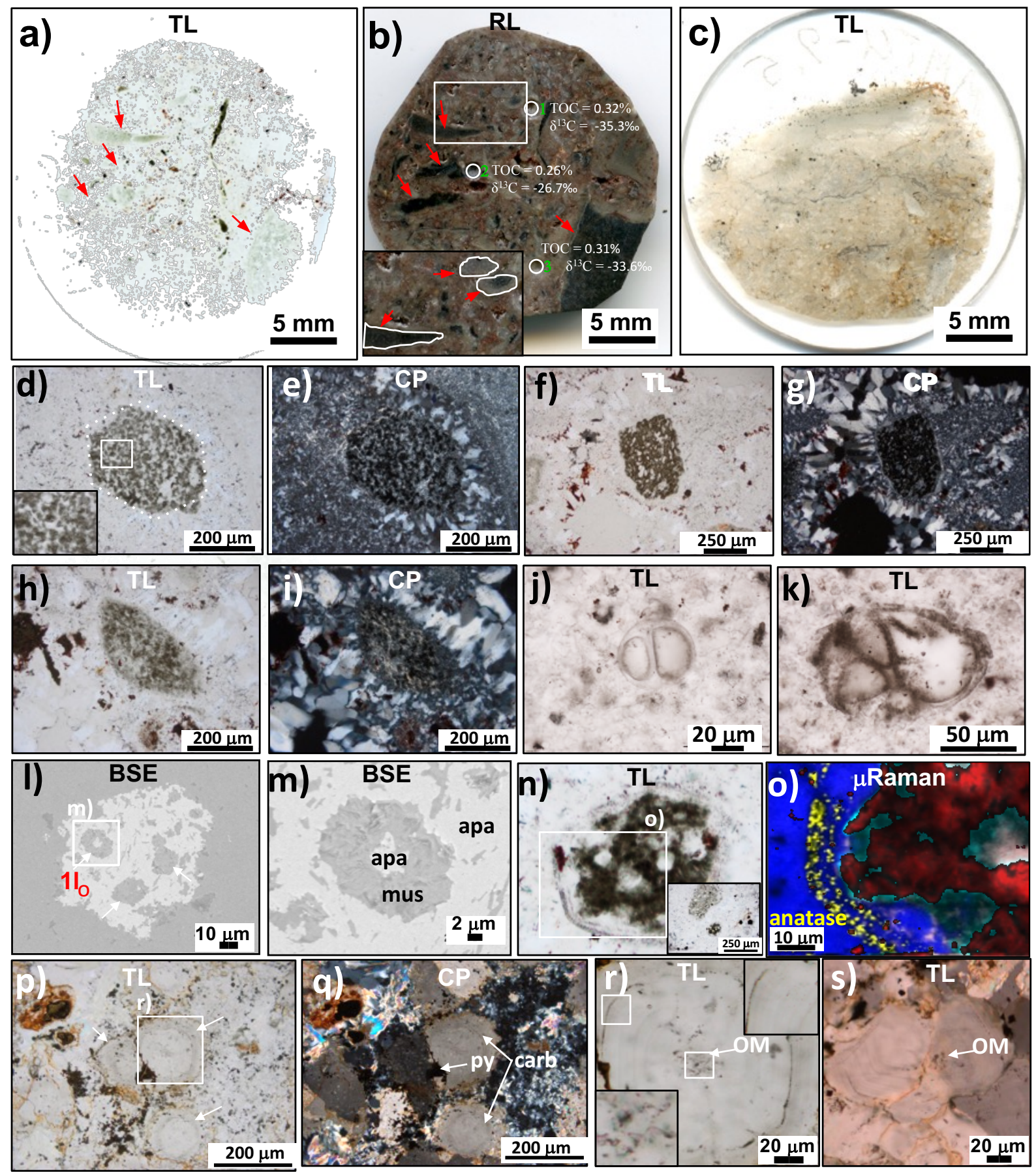

Figure 12: Petrographic context of apatite in phosphatic chert and carbonate from the Michigamme Fm. a-b) transmitted and reflected light images of sample MA0708 (Huron River Locality) with arrows pointing to dark concretionary apatite structures, c) sample MMTU-9.5 (Dead River Basin). Photomicrographs (d-o) are for MA0708: $d-i$ ) apatite granules with OM forming regular patterns shown in greater detail in inset for $d$ ), $j-k$ ) two examples of compartmentalized spheroidal structures composed of apatite and OM in intergranular matrix, I-o) sub-hexagonal granule of apatite-graphitic carbon along with muscovite-sericite rosettes (white arrows) and surrounded by rounded equidistant laminations of nanoscopic anatase (best seen in $n$ and o (yellow)). Sample MMTU-9.5: $p$-s) zoned carbonate granules with concentric rounded equidistant laminations (white arrows) around a center of nanoscopic OM, and intergranular pyrite and Fe-oxide. Abbreviations same as before with mus = muscovite (sericite). Colours in Raman image are blue = quartz, red = graphitic carbon, turquoise = apatite, yellow = anatase. Spot number in panel I) is for an EDS analysis listed in Table 2. 


\section{Figure 13 - Papineau et al. (2017)}
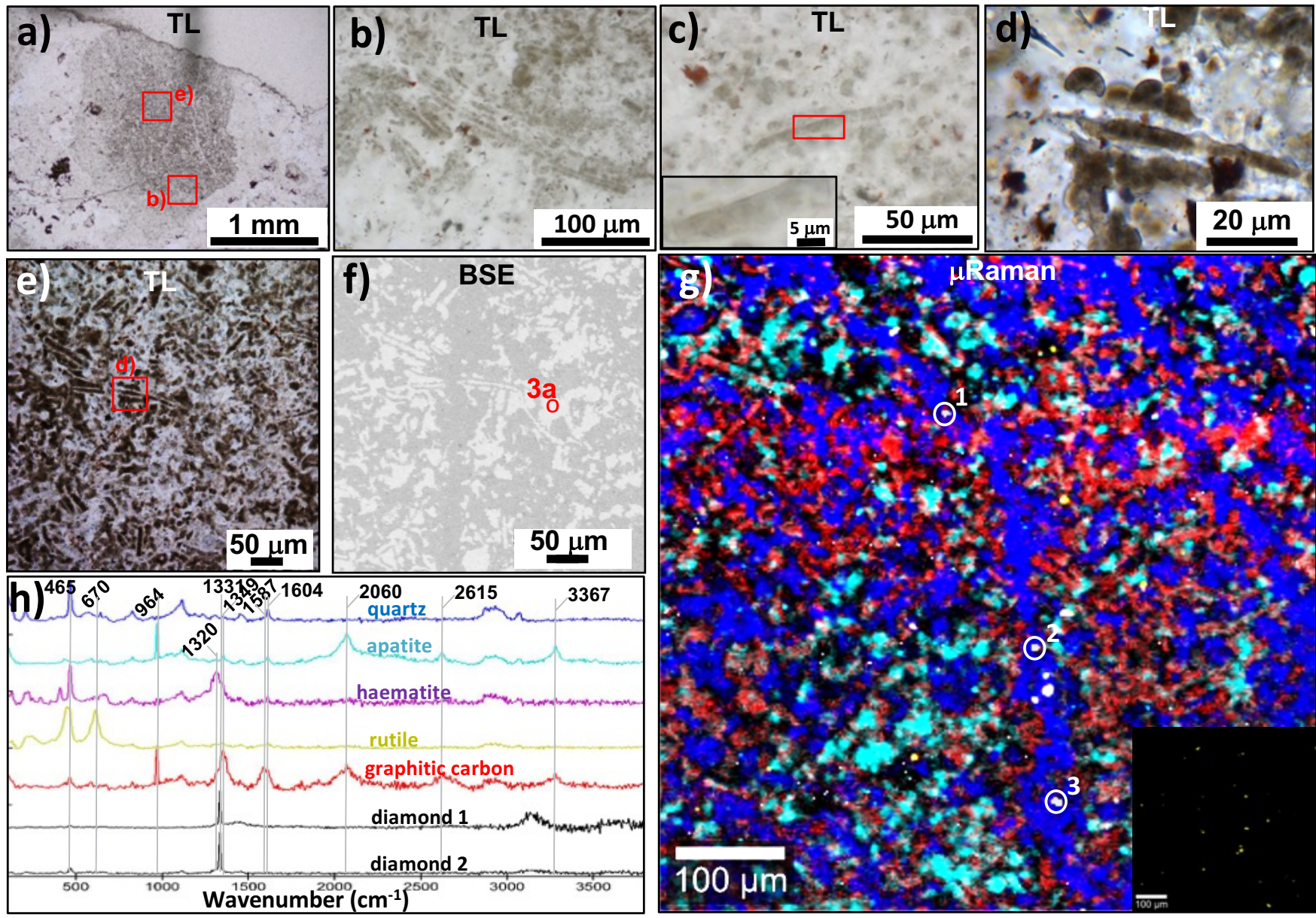

Figure 13: Filamentous structures composed of apatite with OM and associated with haematite and rutile in a granule from the Michigamme phosphatic chert (MA0708). a-f) Groups of filamentous structures composed of apatite and $O M$ inside an apatite granule, $g$ ) Raman image of the apatite granule with filamentous structures (inset shows the $670 \mathrm{~cm}^{-1}$ filter for rutile in the same field), h) Raman spectra of the major minerals in this chert, along with detected contaminant diamonds. Colours are same as before and correspond between the hyperspectral image and the spectra, with purple = haematite and yellow = rutile. Spot number in red (in panel f) is for an EDS analysis listed in Table 2. 


\section{Figure 14 - Papineau et al. (2017)}
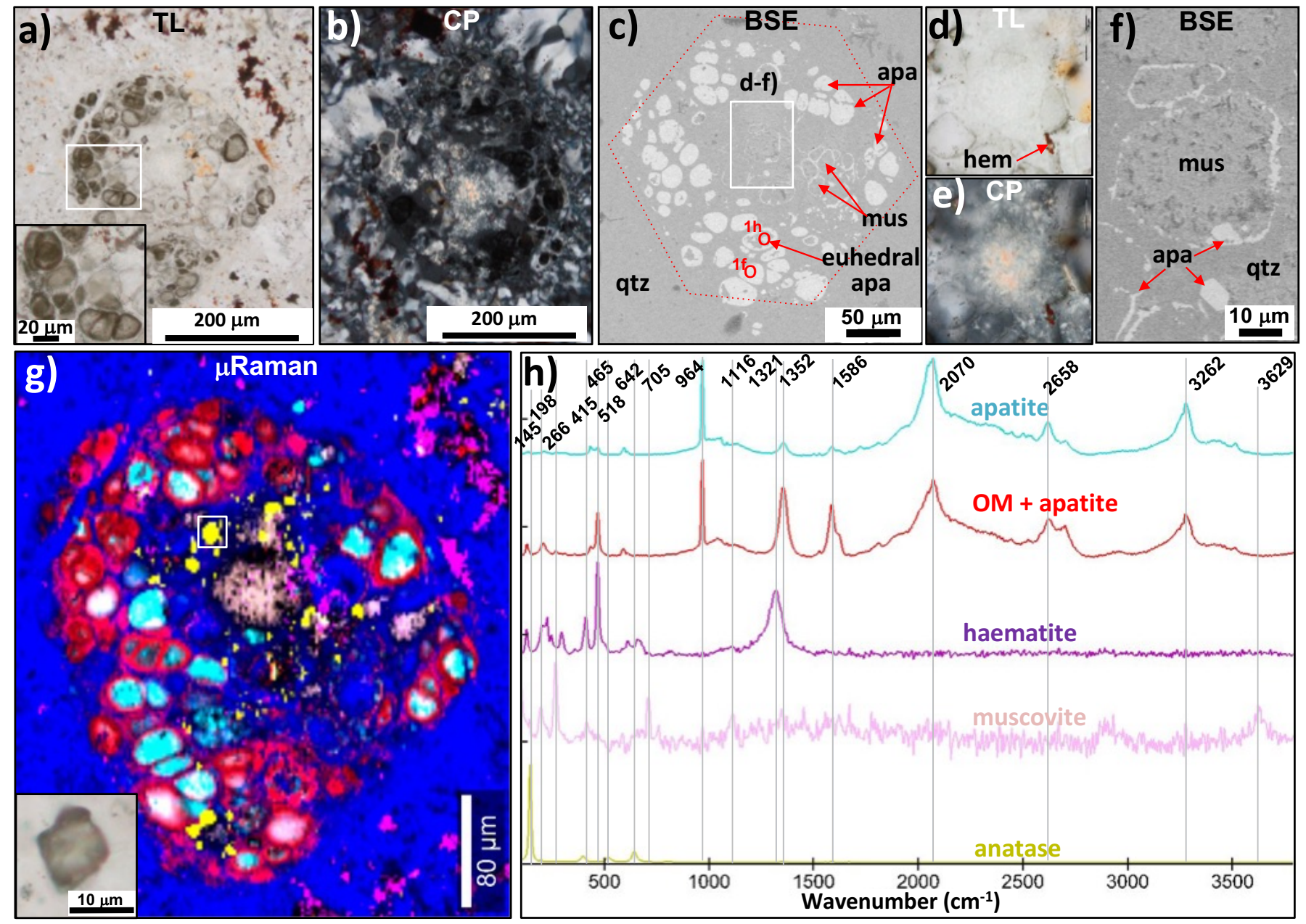

Figure 14: Spheroidal structure in a granule from the Michigamme phosphatic chert. a-c) Images of a granule that contains spheroidal structures composed of $\mathrm{OM}$ with apatite and that form an hexagonal shape (red dotted line in (c)), d-f) images of a muscovite rosette with a rim of apatite located near the center of the granule, g) Raman image of the different phases in this granule based on major peaks in Raman spectra shown in $h$ ). Spot numbers in red are for EDS analyses listed in Table 2. Mineral abbreviations and Raman colour codes are the same as before, and mus = muscovite. Colours in Raman image are same as Fig. 12 with pink = muscovite. 


\section{Figure 15 - Papineau et al. (2017)}

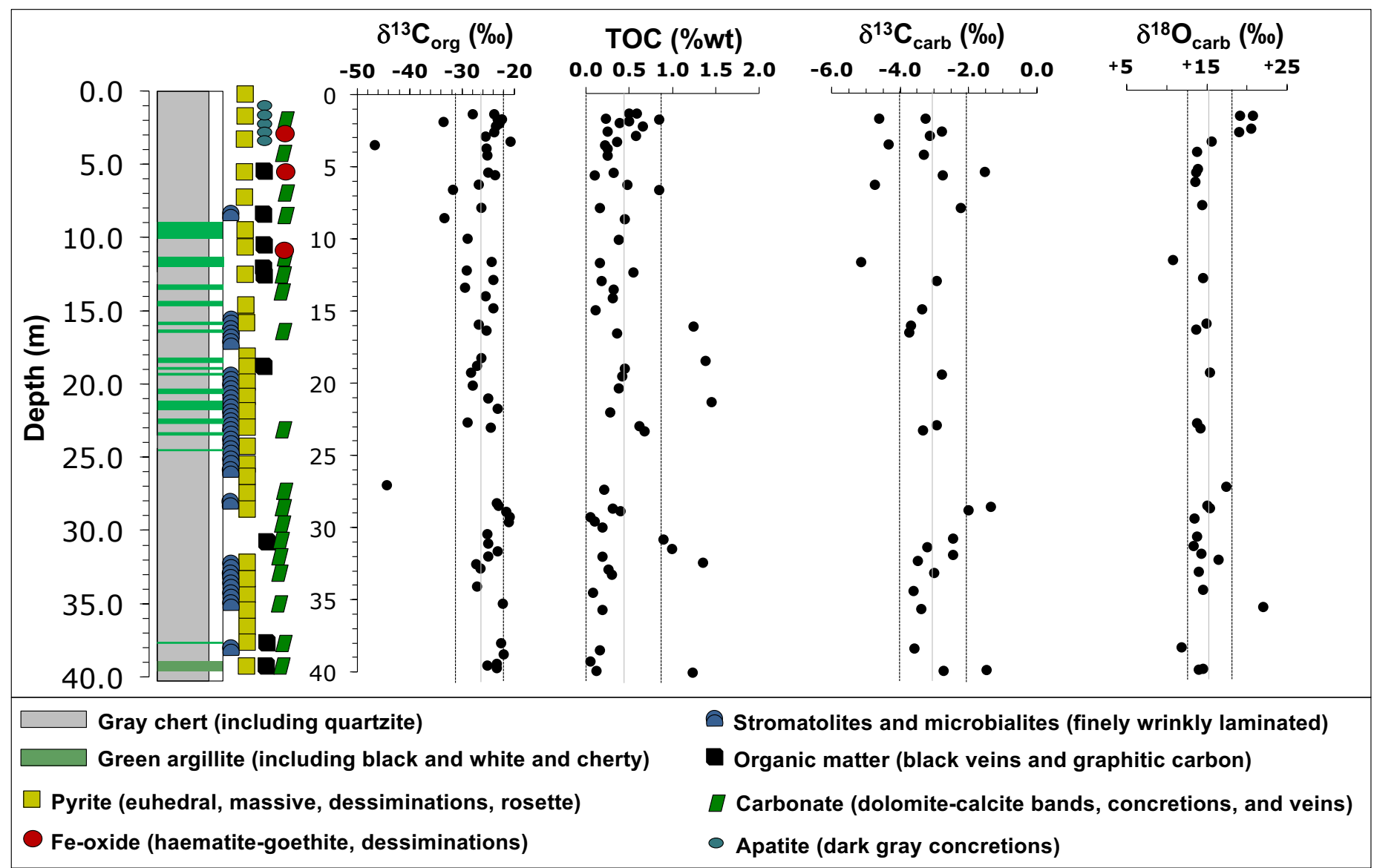

Figure 15: Chemostratigraphic profile of the MMTU drill core from the Michigamme Fm with carbon isotope composition of acid-insoluble OM, total organic carbon (TOC), and carbon and oxygen isotope compositions of carbonate. Vertical lines show averages (light gray) and $1 \sigma$ standard deviations (black). Stratigraphic details modified from IMR drill core log (Mulligan Plains, Sec. 15, R28W, T49N, Marquette County, Michigan). 


\section{Figure 16 - Papineau et al. (2017)}

a) Microbial organic matter in organic-rich silica

\begin{tabular}{|c|c|c|c|c|}
\hline $\begin{array}{l}\text { I. Dead microbial biomass } \\
\text { (red) mixed with EPS (brown) } \\
\text { decomposes and is oxidized } \\
\text { through chemically-oscillating } \\
\text { reactions. }\end{array}$ & $\begin{array}{l}\text { II. Diffusion from oxidation } \\
\text { spots forms fractal patterns of } \\
\text { OM (brown ellipses) along with } \\
\text { of bicarbonate (green) and } \\
\text { sulphide (yellow), which start } \\
\text { precipitating. }\end{array}$ & $\begin{array}{l}\text { III. Lower alkalinity triggers } \\
\text { precipitation of colloidal silica } \\
\text { (white). }\end{array}$ & $\begin{array}{l}\text { IV. Permineralisation in silica leads } \\
\text { to the formation of granules with } \\
\text { rounded equidistant laminations of } \\
\text { OM and diagenetic minerals. }\end{array}$ & $\begin{array}{l}\text { V. Sub-greenschist facies } \\
\text { metamorphism converts kerogen } \\
\text { to graphitic carbon, destroys } \\
\text { most microfossils. }\end{array}$ \\
\hline
\end{tabular}

\section{b) Microbial organic matter in ferruginous silica}

\begin{tabular}{|c|c|c|c|c|}
\hline $\begin{array}{l}\text { I. Biomass adsorbs on detrital } \\
\text { clays and mixes with } \\
\text { hydrothermal ferrihydrite } \\
\text { (purple dots). }\end{array}$ & $\begin{array}{l}\text { II. The oxidation of OM by } \\
\text { ferrihydrite results in oxidation } \\
\text { spots and the replacement of } \\
\text { OM by haematite and the } \\
\text { formation of bicarbonate }\end{array}$ & $\begin{array}{l}\text { III. Fractal patterns of ferrihydrite } \\
\text { and hydromagnetite (yellow } \\
\text { lines) are mixed with diagenetic } \\
\text { carbonate and apatite } \\
\text { (turquoise). }\end{array}$ & $\begin{array}{c}\text { IV. Permineralisation in silica } \\
\text { immobilizes the expansion of } \\
\text { haematite, carbonate, apatite, } \\
\text { magnetite, and oxidised OM (red) } \\
\text { in granules. }\end{array}$ & $\begin{array}{l}\text { V. Sub-greenschist facies } \\
\text { metamorphism destroys most } \\
\text { microfossils and leads to outsized } \\
\text { acicular stilpnomelane and } \\
\text { graphitic carbon. }\end{array}$ \\
\hline & $100 \mu \mathrm{m}$ & & & \\
\hline
\end{tabular}

\section{c) Microbial organic matter in phosphatic silica}

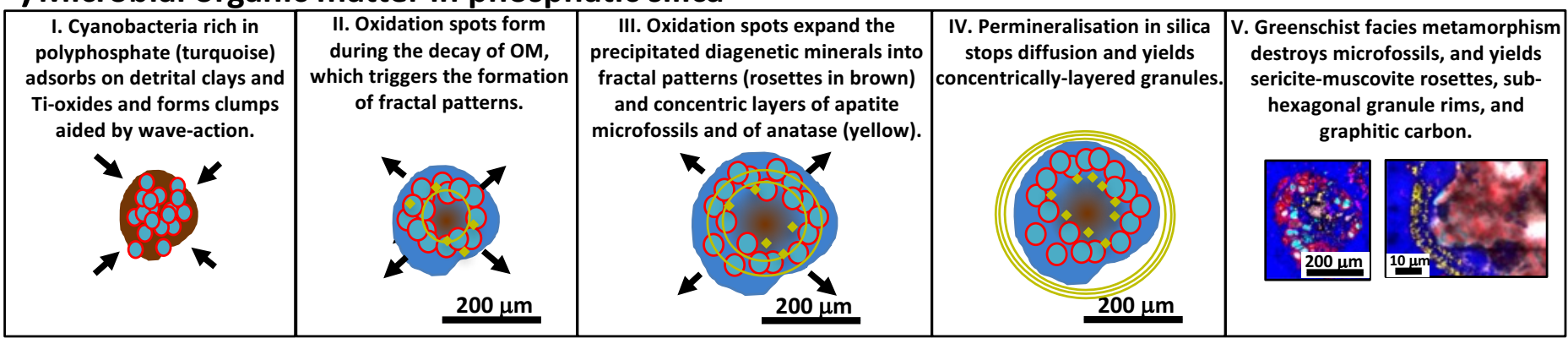

Figure 16: Proposed models for the diagenetic growth of granules from the non-biological oxidation of organic matter in a) organic granular chert (e.g. in Gunflint Fm), b) haematite-rich chert (e.g. in Biwabik Fm), and phosphatic and clay-rich granular chert (e.g. in Michigamme Fm). 